Juha Kuokkala (Helsinki)

\title{
Saami -(̌s)goahti- inchoatives: Their variation, history, and suggested cognates in Veps and Mordvin
}

The purpose of this article is twofold: first, to give an overview of the morphological and areal variation of the Saami deverbal inchoative suffixes (North Saami -goahti-and -šgoahti-), and second, to give an updated account of the history of said suffixes. To achieve the latter, a critical survey is made of previous literature dealing with these Saami suffixes as well as the phonetically and semantically similar derivational suffixes in Mordvin (Erzya -kado-, -gado-) and in Veps and Ludic (-gande-, -škande- $\sim$-gade-, -škade-). Several kinds of etymological cognate or loan relations between these suffixes have been posited. In the present paper, however, it is argued that the Saami -goahtisuffix is not related to other Uralic suffixes, but instead results from the affixation of an independent verb (North Saami boahtit 'to come'). The -š- element attaching to the suffix is explained as a remnant of another derivational suffix still found as an independent inchoative marker -ahtja- present from South Saami up to Lule Saami.

\section{Introduction}

The Saami inchoative suffixes, SaaN -goahti- and -šgoahti- and their variants, are widely used in Saami languages to derive inchoative verbs denoting the beginning of the activity or state expressed by the base verb. The origins of the suffixes are somewhat unclear; they have in previous literature been compared to derivational suffixes with similar functions and phonological appearance in Mordvin (Erzya -kado, -gado) as well as in Veps and Ludic (-gande-, -škande- $\sim$-gade-, -škade-), and various theories about the possible etymological relatedness of these suffixes have been suggested, including partial or full cognation of the suffixes as well as borrowing from one Uralic branch into another; Sammallahti $(1977,1998)$, for instance, derives the Saami suffix from a common Proto-Finno-Volgaic form. In the present paper, the previous explanations are critically assessed and a more elaborate model of the background of Saami -( $\breve{s})$ goahti- based on the affixation of an independent verb is presented, and the $-\check{s}$ - element is given a more solid explanation. In support of the claims made in this reassessment, the distribution of different inchoative suffix variants across the Saami languages is also studied.

The article is structured as follows: Section 2 briefly introduces the central terminology and the transcription used in the language samples. Section 3 contains a survey of the variation of inchoative suffixes across Saami languages (3.1), accompanied by shorter descriptions of the supposedly connected Mordvin and Veps-Ludic suffixes (3.2-3.3). Section 4 gives an overview of the diachronic treatment of the suffixes in previous literature (4.1: Veps-Ludic; 4.2: Mordvin; 4.3: Saami), assesses the tenability of different solutions, and gives a renewed account of the development of 
the Saami suffix family. Section 5 summarizes the results and discusses some aspects of them in the wider context of Saami historical linguistics. ${ }^{1}$

\section{Terminology and transcription}

The term inchoative is generally used to describe the aspectual property of a verb or a clause that refers to the beginning of an action or a state (e.g. Bussmann 1996: 222). The term inceptive is sometimes used synonymously with inchoative (cf. Crystal 1997: 192), although some authors make a distinction by using inchoative with reference to the beginning of states and inceptive to the beginning of actions (e.g. Bybee 1992). The current paper is in line with the tradition of Uralic studies and uses inchoative (verb) as a label for semantically and morphosyntactically defined derivative classes: deverbal verbs with distinct inchoative suffixes, which only change the lexical aspect but not the part-of-speech or valency of the base verb. So the usage is somewhat narrower than in Indo-European studies, where the term "inchoative" is also used in reference to denominal state-change verbs such as to darken or to liquefy, which would belong to distinct categories in the Uralicist classification tradition. These categories include translatives (= transformatives, e.g. Bussmann 1996: 494), and further, automatives ( $\approx$ anticausatives) and reflexives. Translative verbs denote a change of quality or state in the subject, and are usually denominal (de-adjectival) derivatives. Automative and reflexive verbs are derivationally deverbal, but similarly denote a change in the state of the subject caused by the subject itself (reflexive) or with no explicit actor (automative). Both translative and automative verbs are intransitive, and come semantically close to inchoatives, especially those derived from intransitive verbs, in that all these refer to some kind of change in the state of the subject, and the focus is on the new state rather than the old one. The partial semantic overlap can manifest itself in identical morphemes used e.g. both in inchoative and translative

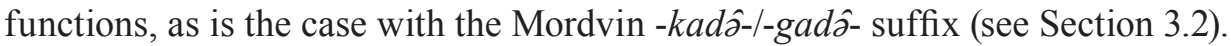

In the language samples used in the current article, the transcription of the Saami languages is converted into current standard orthographies where applicable, Pite Saami according to the working orthography as presented in Wilbur (2016) and Ume Saami according to Barruk (2018). Uralic languages and dialects with no established Latin orthography are quoted according to the source or adapted to a near-phonological transcription using the Uralic Phonetic Alphabet (UPA/FUT). The English translations of the word meanings are in most cases made by the current author on the basis of the glosses given in the indicated sources.

1. I would like to thank Jussi Ylikoski for his useful comments in the finalizing stage of the article. All remaining errors and omissions are naturally my own responsibility. 


\section{Morphology and variation of the western Uralic suffixes}

\section{I. Saami -(š)goahti}

The North Saami inchoative suffix in question has two morphological variants: -goahti- and -šgoahti-. Any verb stem can serve as a basis for derivation, but the suffix variants have a complementary distribution: -goahti attaches to bisyllabic and contracted stems, while -šgoahti- attaches to trisyllabic - and, in the eastern dialects, also to contracted — stems (Nickel 1994: 262-263; Nielsen 1979 [1926]: 247-248). In Nielsen's description (ibid.), the longer suffix variant incorporates the preceding $i$ (-išgoahtit), which can equally be analyzed as the (infinitive) stem vowel of the trisyllabic base verb.

\begin{tabular}{|c|c|c|}
\hline $\begin{array}{l}\text { lohka-t } \\
\text { 'to read' }\end{array}$ & $\begin{array}{l}\text { lohka-goahti-t } \\
\text { 'to begin to read' }\end{array}$ & (bisyllabic) \\
\hline $\begin{array}{l}\text { liihko-t } \\
\text { 'to like' }\end{array}$ & $\begin{array}{l}\text { liihko-(s) goahti-t } \\
\text { 'to begin to like' }\end{array}$ & (contracted) \\
\hline $\begin{array}{l}\text { muitali-t } \\
\text { 'to tell' }\end{array}$ & $\begin{array}{l}\text { muitali-šgoahti-t } \\
\text { 'to begin to telll' }\end{array}$ & (trisyllabic) \\
\hline
\end{tabular}

The suffix - $(\check{s})$ goahti- always has a secondary word stress on its first syllable, and the derivatives are conjugated like bisyllabic verbs:

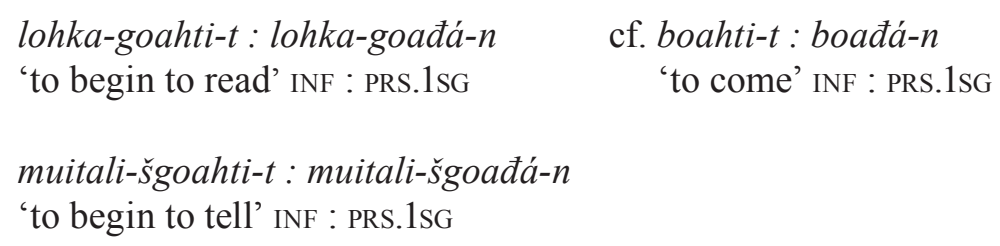

The diphthong $o a$ in the suffix is also peculiar, since it normally appears only in main-stressed initial syllables. Nickel (1994: 263) thus characterizes -goahti- verbs as "compound verbs" (sammensatte verb), and according to Nielsen (1979 [1926]: 248), they lie on the border between derivatives and compounds.

The -goahti- inchoatives have cognates in all Saami languages, and the suffix can be reconstructed into Proto-Saami as *-koate- $\left({ }^{*}\right.$-Goatie- $:{ }^{*}$-GoaD $\bar{a}$ - in allophonic notation). According to Sammallahti (1977: 193), the languages west of North Saami use only the variant without $-\check{s}$-, whereas the eastern Saami languages apply the suffix with -š- to all kinds of verbs without stem type restrictions, and the plain $\check{s}$-less variant has become more or less marginal. The following brief survey describes the variation in more detail, and shows that the picture, especially in the western Saami languages, is more complex than this. While this section is mostly descriptive in 
nature, some remarks on diachrony are already made based on the assumption that the distribution and the functions of the -(̌s)goahti- suffixes in North Saami reflect a relatively original (Proto-Saami) state of affairs, as supported by the evidence from the Saami language area as a whole.

From Skolt, Kildin and Ter Saami, T. I. Itkonen (KKLS, 1958) records both *-koate- and *-škoate- types of suffixes; *-koatē- has its initial stop regularly voiced and spirantized after voiced sounds (in Paatsjoki Skolt and Akkala Saami even to $-v$-):

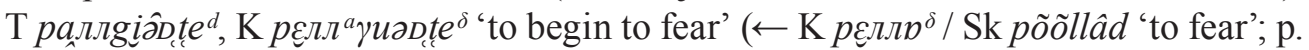
352), Sk(P) jiellevue'tted 'to begin to live' ( $\leftarrow$ jiellet 'to live'; p. 60, 830). ${ }^{2}$ In the Skolt Saami grammar by Feist (2015: 119), only the inceptive (= inchoative) derivative suffix $-s ̌ k u e^{\prime} t t$ - is mentioned. The marginality of the $\check{s}$-less suffix in Skolt Saami is illustrated by the fact that the dictionaries of Mosnikoff \& Sammallahti (1988) and Sammallahti \& Mosnikoff (1991) contain 125 verbs in -škue'tted (affixed to 77 bisyllabic, 38 trisyllabic, and 10 quadrisyllabic stems) but only one š-less *-koatē- verb with two variants: rämmguẹ'tted $\sim$ rämmvuẹ'tted 'to rejoice'. As expected with a suffix beginning with a consonant cluster, the -škue'tt- derivatives based on parisyllabic verbs show a weakgrade consonant center with facultative vowel and consonant shortening in the base, as illustrated by looggškue'tted logškue'tted 'to begin to read' from lookkâd 'to read' (cf. Feist 2015: 119). Also in Kildin and Ter Saami, the inchoatives in -šk- seem generally to be built on the weak-grade stem of the base verb, while the stem before a simple $-g-/-\gamma$ - is in the strong grade (cf. Szabó 1987: 70-71; Szabó 1968: 114, 116). To mention some areally more restricted variants, at least in Voronensk dialect of Kildin Saami, the suffix with $-s ̌ k$ - has been reduced to $-\check{s} \chi$ - and further to $-\check{s}$-, as in sircškude $\sim$ śirešude '(he/she) began to play', tonn śireš $\chi u d d i \chi$ 'you began to play' (Szabó 1967: 23; 1987: 77). In Skolt Saami, a shortened form of the inchoative suffix, -(̌s)kü̈-, is in use beside the longer variants, e.g. $\check{k} i \tilde{c} \check{c}-\check{s} k u \ddot{a}-m$ 'to look at'-INCH-PRs.1sG (Markus Juutinen, pers. comm.).

As there has been no specific research before on the morphological variation of the Skolt and Kola Saami inchoative suffixes (Szabó 1987 focuses on their syntax and semantics), I have gathered two sets of data on the topic. The first data set consists of the verbs in the examples of Szabó 1987 (an illustrative sample, ca. 29\% of his whole, unpublished material; Kld 66/251, T 33/87), added with the inchoative verbs found in the texts in Szabó 1968. The second data set consists of the inchoative verbs in KKLS within the alphabetical span of A-K, merging the data of volumes I and II (ca. 23\% of the total lexical material measured in the volumes). Both data sets reveal a clear pattern in the distribution of $*_{-k o a t e}-$ and $*_{-}-s k a t \bar{e}-$ variants: When attached to an originally trisyllabic stem, the ${ }^{*}-\check{s} k$ oate- - suffix is virtually exclusive. With originally bi- and quadrisyllabic stems, however, Kildin Saami aligns with Skolt Saami by using mostly *-škoate- - and only in specific cases *-koate-, while Ter Saami seems to have

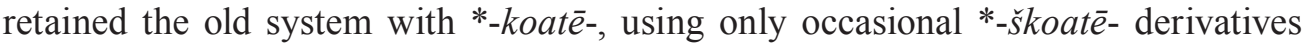

2. Cf. Skolt comitative plural ending -vui'm < *-ku(o)jm(ē) and $\operatorname{Sk}(\mathrm{P})$ čää'zzvué'tkes (S) čää'3zguẹ'ť̌es 'water vole' < čää'33 'water.GEN' + kuẹ'ťkes. Cf. also T. I. Itkonen 1958: XXXII. 
with bisyllabic verbs (see Tables 1, 2 and Figure 1). The few Akkala Saami samples follow the pattern of Skolt and Kildin Saami. As can be seen in Figure 1, the number of derivatives in *-koaté-, used either exclusively or in parallel with $*_{-s}$ koate- in the same stem, increases from the westernmost Skolt dialects (Paatsjoki and Suõ'nn'jel) to Nuõ'ttjäu'rr and further to Kildin Saami.

\begin{tabular}{|c|c|c|c|c|c|c|}
\hline orig.stem & \multicolumn{3}{|c|}{ Kildin } & \multicolumn{3}{c|}{ Ter } \\
\hline syllables & $* \mathrm{k}$ & $* \mathrm{k} / \mathrm{s} \mathrm{k}$ & $*$ šk & $* \mathrm{k}$ & $* \mathrm{k} / \mathrm{s} \mathrm{k}$ & $*$ šk \\
\hline 2 & 8 & 2 & 28 & 27 & 1 & 4 \\
\hline 3 & - & - & 10 & 1 & - & 7 \\
\hline 4 & - & - & 11 & 2 & - & - \\
\hline
\end{tabular}

Table I. Inchoative suffix variants in Szabó 1987 and Szabó 1968 (number of distinct base verbs). $*_{\mathrm{k}}=*_{\text {-koatē-, }} *_{\text {šk }}=*_{\text {-škoatē-, }} *_{\mathrm{k}} / *_{\text {sk }}=$ both.

\begin{tabular}{|c|c|c|c|c|c|c|c|c|c|}
\hline orig.stem & \multicolumn{3}{|c|}{ Skolt $(\mathrm{P}+\mathrm{S}+\mathrm{N})$} & \multicolumn{3}{|c|}{ Kildin } & \multicolumn{3}{|c|}{ Ter } \\
\hline syllables & $*_{\mathrm{k}}$ & *k/šk & *šk & $* \mathrm{k}$ & $*_{\mathrm{k}} / \mathrm{s} \mathrm{k}$ & *šk & $*_{\mathrm{k}}$ & ${ }^{*} \mathrm{k} / \mathrm{s} \mathrm{k}$ & $*$ šk \\
\hline 2 & 5 & 2 & 94 & 8 & 7 & 31 & 22 & - & 2 \\
\hline 3 & - & - & 34 & 2 & - & 14 & 1 & - & 10 \\
\hline 4 & - & - & 9 & - & - & 6 & 1 & - & - \\
\hline
\end{tabular}

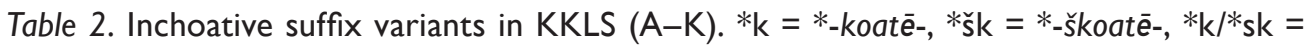
both. 


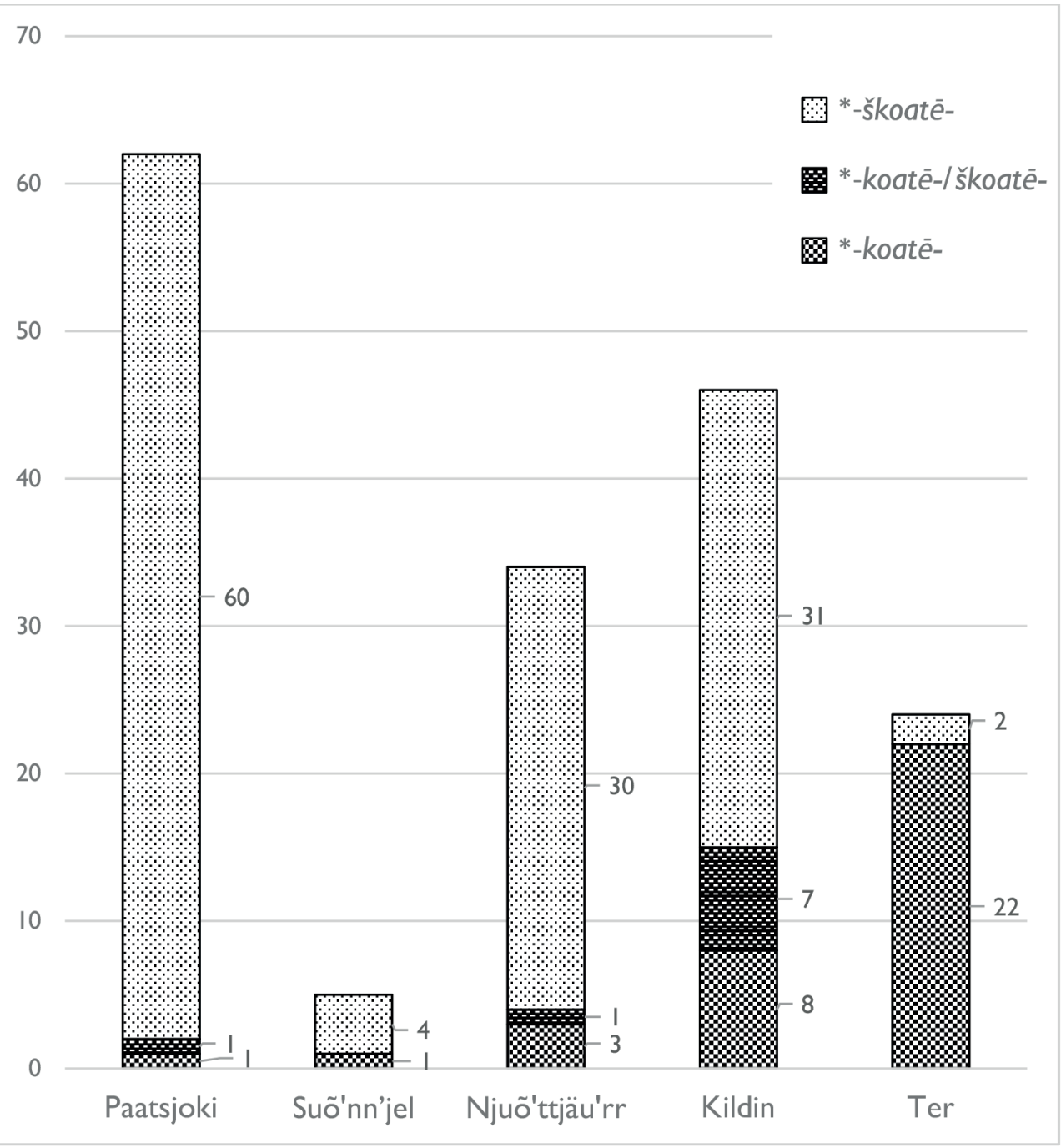

Figure I. Inchoative suffix variants attached to bisyllabic verb stems in different dialects in KKLS (A-K).

While the proportions of the numbers in KKLS and Szabó data are rather similar, the actual lexemes making up the two data sets overlap only partly. Between dialects, the dispersion is considerable: most of the individual derivatives are attested only from one or two dialects (consider that in the KKLS data, there are altogether 262 mentions of derivatives representing 172 verb bases, mostly distributed among the four dialect areas $\mathrm{Sk}[\mathrm{P}], \mathrm{Sk}[\mathrm{N}], \mathrm{K}, \mathrm{T})$. Only a few verbs have a widely recorded range, including Sk jie'llevuẹttted (P, S, K, T) jeä'lškuẹttted $(\mathrm{P}, \mathrm{N}, \mathrm{K})^{3}$ 'to start living', â'psškuẹ'tted

3. In Szabó’s data also Ter Saami: jeíliš̌kēdDin (aftsijestt) ‘begannen (miteinander) zu leben’ (Szabó 1968: 56). 
(P, S, N, K) 'to begin to stink' and kiorrggneškuẹ'tted 'to begin to get ready' (P, N, K, T) (KKLS: 60, 830, 22, 814, 120).

Especially in those dialects where simple *-koate- derivatives are rare, they often express some special lexicalized meanings instead of just beginning, e.g. K jạmmguวdț $\delta$ 'to faint' (also T) $\leftarrow$ jă $m m e^{\delta}$ 'to die' (KKLS: 49). Sk(S) jie'llevuẹ'tted and its cognates in Skolt and Kildin Saami mean 'to settle down, start living (somewhere)', while the Ter word also often means 'to keep on living' in certain narrational contexts (KKLS: 60, 830; Szabó 1987: 95-96). Sk(N) rämmguẹ'tted $\sim(\mathrm{P})$ rämmvuẹ'tted 'to rejoice' even lacks an evident base verb and seems instead to be derived from the noun rämm 'joy'; $\mathrm{Sk}(\mathrm{P})$ johlvuẹ'tted 'to prepare serving' and its apparent correlate (S) joohleed 'to romp about' possibly originated independently from Finnish juhla 'feast, party' (KKLS: 420, 66, 833). In Ter Saami, the inchoative aspect of $*_{-}(\check{s})$ koate- derivatives is commonly overrided by a future interpretation when used in present tense (Szabó 1987: 98-102).

Inari Saami uses the ${ }^{*}-s k$ kote $\bar{e}$ - suffix as a neutral inchoative suffix with all kinds of base verbs, while the *-koate- suffix variant is largely used in subitive or momentary meaning, e.g. šurragyettid 'to (suddenly) make a buzz' (Sammallahti 1977: 193; InLpWb $\S 608,4726,4807.2)$. The diphthong of the suffixes has shifted from original *oa to the Proto-Saami *uo type, as in skillâgyettiđ: PST.3sG skillâguođij 'to (suddenly) chink; crash,' though variants with *oa have also been recorded, cf. skillâguáttiđ 'id.' (InLpWb § 608, 4261.2).

For a comprehensive data set comparable with the Skolt and Kola Saami data, I have collected all the verbs with these suffixes presented in Inarilappisches Wörterbuch (InLpWb), which comprise 80 derivatives in -gyetti-/-guátti- and 208 in -škyetti-/škuátti-. The -škyetti-/-škuátti- verbs show uniformly inchoative semantics and represent all types of base stems, even the monosyllabic leđe 'to be' $\rightarrow$ leškyettid 'to begin to be' (InLpWb $\S$ 2041.2), which seems to be unique among the Saami languages. More than half of the -gyetti-/-guátti- derivatives are attested in a subitive/momentary meaning (sudden, short, or occurring once), while an inchoative (beginning) meaning is also almost as common. A number of derivatives have been recorded in both senses, e.g. viccâgyettid 'to squeak, cheep (once)' or 'to begin to squeak, cheep' (InLpWb $\S 5534.2$ ). Virtually all of the subitive/momentary and many of the inchoative -gyetti-/-guátti- derivatives are based on onomatopoetic or generally sound-symbolic stems and usually do not have a formal base verb, but instead have correlate verbs in -ijdiđ and verbal nouns in -ân, such as kommâgyettiđ 'to boom (once)' - komijdid 'to boom, rumble' - koommân 'booming, rumbling (n.)' (InLpWb $\S 1660$ ). This pattern or derivational paradigm (cf. Štekauer 2014) seems to be rather productive and can be compared to the Finnish expressive verb pattern kumahtaa kumista - kumina 'id.' There are also a couple of translative-inchoative derivatives that could be analyzed as noun-based, e.g. ávvugyettiđ 'to be delighted', cf. áávvu ávvu 'joy, delight' and ávvudiđ 'to be happy' (InLpWb § 107).

The -gyetti-/-guátti- derivatives are based on bisyllabic strong-grade vowel stems, except for a group based on $-r$-stems, all of which have a verbal correlate in 
-rdid and some also a noun correlate in $-r$ (e.g. skuipergyettid 'to begin wandering around'; skuiperdid 'to wander (alone)'; skuuiper 'a lone animal' [InLpWb § 4331]). The -škyetti-/-škuátti- derivatives again, in concord with the Skolt and Kola Saami data, require a weak-grade base stem when attached to a parisyllabic verb, as exemplified by cogâškyettiđ $\leftarrow$ coggâd 'to support', cahâškyettiđ $\leftarrow$ cakkâd 'to groan', šovvoškyettiđ $\leftarrow$ šohhoođ 'to puff, hiss' and skyennidâđâškyettiđ $\leftarrow$ skyennidâttâd 'to be capricious' (InLpWb $\S 200,202,4777,4336$ ). In contrast to the verbs with inchoative semantics, the subitive -gyetti-/-guátti- verbs can serve as a base for further derivatives, such as kicâgyettid 'to creak (once)' $\rightarrow$ kicâgyeđettid 'to make something creak (once)', šuđđâgyettiđ šuđđâguáttiđ 'to hiss (once/suddenly)' $\rightarrow$ šuđđâgyeđestiđ 'to hiss a little' and even $\rightarrow$ šuđđâguáđástâllâđ 'to hiss a little every now and then' (InLpWb $\S 1424,4797$ ).

Thus, the development of generalizing the $*_{-s} k$ kote $\bar{e}$ - and marginalizing the *-koate- inchoative suffix, observable in Skolt and Kildin Saami, has only a partial counterpart in Inari Saami: while the -škyetti-/-škuátti- suffix has become a neutral inchoative suffix usable with all stem types, the -gyetti-/-guátti- suffix has remained in use with expressive verbs and in this environment has taken up a new function as a subitive/momentary suffix with a productive derivation pattern. The extant *-koateinchoatives in Kildin Saami also show an inclination towards sound-symbolic or sound-denoting verbs (e.g. kōrsGuวDte $\delta$ 'to start snoring'; KKLS: 865). Finally, it is worth mentioning that the exceptional derivative $\mathrm{Sk}(\mathrm{N})$ rämmguẹ'tted (also $\mathrm{P}, \mathrm{K}$ ) 'to rejoice' ( $\leftarrow$ rämm 'joy') has a close semantic and derivational parallel in the small group of translative-like derivatives with no direct base verb in Inari Saami, which contains verbs denoting a shift into a mental state: SaaI ávvugyettiđ 'to be delighted', ilogyettid 'id.' (ávvu = ilo 'joy, delight', ávvudid=ilodid 'to be happy, rejoice'; InLpWb $\S 107,907)$, kimegyettid 'to get ruttish, in heat' (kime 'rut, heat', kimedid 'to be in rut/ heat'; InLpWb § 1501), skyenigyettid 'to get angry/capricious' (InLpWb § 4336) and vyerigyettid 'to get muddle-headed (reindeer)' (InLpWb § 5668).

Pite and Lule Saami: In contrast to Sammallahti's (1977: 193) generalization, there seems to be syllable count-based form variation also in the Saami idioms west of North Saami. In Pite Saami, the suffix -gåhte- is only attached to bisyllabic and contracted stems (bassa-t 'to wash' $\rightarrow$ bassa-gåhte- $t$ 'to begin to wash'), while trisyllabic stems get a longer suffix -atjgåhte- (báhkadi-t 'to get warm' $\rightarrow$ báhkad-atjgåhte-t 'to begin to get warm') (Ruong 1943: 219-222; Lehtiranta 1992: 29). Ruong (ibid.) analyzes the latter type as a re-derivation of inchoatives in -áhtja- (báhkad-áhtja-t $\rightarrow$ báhkadatj-gåhte- $t$ ) and thus the formant -atjgåhte- represents a combination of two inchoative suffixes. In Lule Saami, the situation is somewhat similar, although the longer

4. The complete list of these verbs with their original glosses and entry indices in InLpWb: čuučârgyettid 'brodelnd zu kochen beginnen' (418.2), havdârgyettiđ 'brenzlig zu riechen, zu rauchen beginnen; zu dampfen beginnen' (616.4), kazârgyettiđ 'toben anfangen' (1124.3), molârgyettiđ 'einmal brummen' (2486.2), skuipergyettiđ 'anfangen herumzustreunen' (4331.4), teibârgyettid 'zu zappeln beginnen (Fisch im Boot); kurze Zeit zappeln' (4943.2), tuohkurgyettiđ 'anfangen zu toben, zu ringen' (5147.2). 
suffix -asjgoahte- has a sibilant instead of an affricate and is quite sparsely attested (the dictionary of O. Korhonen [2007] only has two examples: dálkkuhasjgoahtet $\leftarrow$ dálkkuhit 'to be bad weather' and rássjodasjgoahtet $\leftarrow$ rássjodit 'to rain heavily [with wind]'; cf. also Kintel 1991: 49). Variants with a connecting vowel $-i$ - have also been recorded, as in lárkatjasjgoahtet rárkatjisjgoahtet 'to begin separating reindeer' (Grundström 1946-1954: 395, 831). ${ }^{5}$ Comparable to Pite Saami -áhtja- (Ruong 1943: 134-137), a more common inchoative suffix for trisyllabic stems in Lule Saami seems to be -ahtja- (e.g. dádjadahtjat 'to begin to understand' $\leftarrow$ dádjadit 'to understand'; altogether there are 21 examples in O. Korhonen 2007).

From Ume and South Saami, only *-koate- inchoatives with bisyllabic base stems have been documented. Some examples from Ume Saami: gålggagåhtiet 'to begin to flow' $\leftarrow$ gålggat 'to run, flow', gualdduogåhtiet 'to begin snowing heavily' $\leftarrow$ gualdduot 'to snow heavily'; and South Saami: voejegåetedh 'to start swimming' $\leftarrow$ voejedh 'to swim'. There are some apparent examples of a $*$-koate- derivative based on a trisyllabic stem truncated to bisyllabic (SaaS snijhkiegåetedh 'to start crying' $\leftarrow$ snijhkiedidh 'to cry'), but usually inchoatives of trisyllabic verbs seem to be formed with SaaU -áhtja- (dájjadáhtjat 'to begin to understand' $\leftarrow$ dájjadit) and SaaS -ahtje-/-ihtje- (valkesahtjedh 'to begin/prepare to set off' $\longleftarrow$ valkesidh, gåhkasjïhtjedh 'to begin to think that someone has stayed away long' $\leftarrow$ gåhkasjidh). The latter suffix combined with inchoative $-j$-, resulting in the suffix -jahtje- (Hasselbrink: -jittj'e-), can also be used with bisyllabic stems, e.g. SaaS hajkijahtjedh 'to start running' $\leftarrow$ hajkedh 'to run'. (Sources for Ume Saami: Schlachter 1958; Barruk 2018; and South Saami: Bergsland \& Magga 1993; Bergsland 1994: 92; Hasselbrink 1981-1985: 179.)

Old grammars and dictionaries: According to early grammatical descriptions, the *-škoate- inchoative with a weak-grade bisyllabic base stem, characteristic of the eastern Saami languages, has also been used as a variant in some North Saami dialects. Leem in his grammar of the mountain dialect of Porsanger (Leem 1748: 283295) presents the alternative derivatives:

- 〈Lokkagoaadam〉 〈Logasgoaadam〉 'Jeg begynder at læse'

$[\leftarrow$ modern SaaN lohkat $]$,

- 〈Adnegoaadam〉 $\sim$ Anesgoaadam〉 'Jeg begynder at bruge' [atnit],

- 〈Lodnogoaadam〉 〈Laanosgoaadam〉 'Jeg begynder at bytte' [lotnut],

- 〈Rawegoaadam〉 〈Rawesgoaadam〉 'Jeg begynder at befale' [rávvet]

(Rask 1832: 132-133, quoting Leem 1748, writes 〈lokkagà̀dam〉 and 〈logasgà̀dam〉). For trisyllabic stems, Leem gives the longer suffix variant, as in «Mon Dobdastam〉 : 〈Dobdastesgoadaam〉 'Jeg begynder at bekiende'. The sibilant 〈S〉 in 〈-sgoaadam〉 is

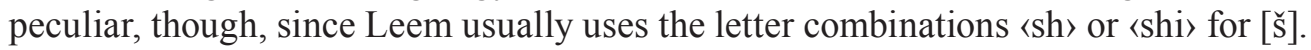
While it perhaps cannot be completely ruled out that the notation could reflect some

5. Grundström's above-cited example with -asjgoahtet is from Northern Jokkmokk and the one with -isjgoahtet is from Central Jokkmokk, so at least any clear north-south dialectal division cannot be inferred, although the few other examples of Grundström containing -isjgoahtet (hurádisjgoahtet 'to start humming to oneself', p. 1336; allånisjgoahtet 'to begin to be ready', p. 1500) are from Northern Gällivare, which is nowadays usually classified as a Torne Saami (North Saami) dialect. 


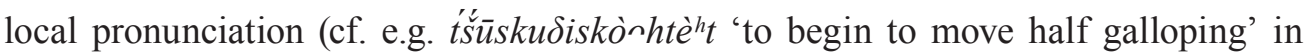
the Jukkasjärvi dialect of Torne Saami, where $\check{s}>s$ occurs regularly; Collinder 1949: $275,289),{ }^{6}$ it is more likely that this is only a matter of inconsistent orthography and the actual pronunciation was $[\check{\mathrm{s}}] .^{7}$ The inspection of Leem's Lexicon Lapponicum (1768) reveals another kind of pattern: The inchoative derivatives of bisyllabic stems have regularly a suffix in 〈-goaadam〉 and contracted stems in 〈-shgoaadam〉 (e.g. 〈ællegoaadam〉 $\longleftarrow$ «lam〉 'lever / vivo', 〈addishgoaadam〉 $\leftarrow$ 〈addim〉 'forstaaer -- / intelligo --'). Trisyllabic stems are treated varyingly in different parts of the dictionary: from the beginning until ca. page 110 there are plenty of inchoatives with the suffix 〈-esgoaadam〉 (the last one is 〈bavzhjastesgoaadam〉), then in pages ca. 127-608 with the suffix 〈-ishgoaadam〉(biettelishgoaadam〉-〈Jollardishgoaadam〉, ca. 100 words), but after this, the trisyllable-based inchoatives become less frequent, and the whole latter half of the dictionary (after page 841, 〈Murtotishgoaadam〉) contains only three derivatives in 〈-ishgoaadam > and two in 〈-esgoaadam». Thus it seems as if Leem changed his orthographic practice with the last derivative type during the composition work to better correspond to the pronunciation. There is also a clear-cut regularization concerning the derivatives of bisyllabic and contracted stems, which could still both have suffixes with or without 〈S〉 according to the 1748 grammar. This likely suggests that the *logaškoahtēt type was already dying out in East-Finnmark and that the current suffix distributions were being established.

The grammar of Ganander (1743) based on Torne Saami corresponds to the eastern rather than the western varieties of modern North Saami in its distribution of inchoative suffixes (p. 67):

- $\quad$ Bisyllabic stems get 〈-kådam〉 (〈lågcadt $\rangle \rightarrow\langle$ logcakådam〉 'legere' [lohkat $]$ )

- Contracted stems get $\langle$-skådam $\rangle$ (〈faddidt $\rangle \rightarrow\langle$ faddiskådam $\rangle$ 'mittere' [sáddet] $)$

- Trisyllabic stems get 〈-skådam〉 (〈wi Kkuodedt $\rangle \rightarrow\langle$ wilkuodeskådam〉 'flavefcere' [fiskkodit])

- Quadrisyllabic - uvva- verbs get 〈-skådam〉 attached to the full or shortened stem («mätzaidowat〉 $\rightarrow$ 〈mätzaidowas-/mätzaidoskådtet〉 'fylvefcere' [meahcáiduvvat]); cf. SaaI pillâšuu-škyettiđ $\leftarrow$ pillâšuđ : $\mathrm{PRS} .3 \mathrm{SG}$ pillâšuvâ 'to be spoiled' (InLpWb § 3312).

Ganander's orthographic 〈sk〉 apparently stands for pronounced [šk], since a nonword-final [s] is consistently written with a long 〈§〉, e.g. p. 68 〈låneftam〉, 〈lånefteftam〉 and (above) 〈wilkuodedt〉.

The North Saami grammar of Stockfleth (1840: II:160-161) presents inchoatives in 〈-goattet〉 for bisyllabic verbs («Låkkagoattet〉,〈Årrogoattet〉) and 〈-šgoattet〉 for

6. There is also a mention from Kvænangen dialect of Sea Saami about variation $\breve{\zeta} \sim \check{s} \sim s$ in the potential marker (Lagercrantz 1929: 209), but the variant with $s$ occurs only in the paradigm of parisyllabic $u$-stems, which leads one to suspect that these exceptional forms have been influenced by the

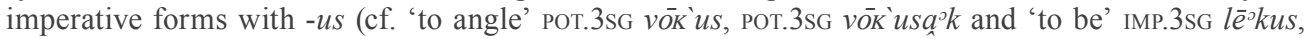
IMP.3SG lèskusa`k; ibid. pp. 209, 203).

7. Note that according to Kemi (1994: 56), the suffixal št cluster was also written as 〈st〉 in Leem's work (e.g. 〈duodastussa〉). 
longer verbs irrespective of their syllable count (〈årrostišgoattet〉, 〈årrostastišgoattet)). While this may somehow reflect the distribution of some eastern North Saami dialects of that time (Stockfleth worked in Vadsø near the Russian border not far from the Skolt Saami area), it should be noted that at least the massive derivative trees at the end of the grammar seem to be partly mechanically construed (there, even the bisyllabic 〈čuovggat〉 gets a «-škoattet〉 inchoative!), so Stockfleth may have made false generalizations. It is anyway suspicious that all the 〈-škoattet〉 derivatives of parisyllabic verbs are formed with a strong-grade stem, contrary to all the data about corresponding derivatives in eastern Saami as well as in Leem's grammar.

The "Swedish Lapp" dictionary of Lindahl and Öhrling (1780) contains more than one thousand inchoative derivatives, which follow the pattern later documented from Pite Saami by Ruong (1943): 〈aitset〉 $\rightarrow$ 〈aitsegåtet〉 'to begin to notice'; 〈ajatallet〉 $\rightarrow$ 〈ajatallegåtet〉 'to begin to consider'; 〈kuostetet〉 $\rightarrow\langle$ kuostetatjet〉, 〈kuostetatjegåtet〉 'to begin to get cold'. The material also resembles current Ume Saami data except for the type 〈kuostetatjegåtet〉. These observations are consistent with the usual claim that the old Swedish Saami literary language and consequently the work of Lindahl and Öhrling is largely based on Ume Saami, with features also from Pite and Lule Saami (e.g. Korhonen 1981: 55). Fiellström's grammar (1738: 49) gives similar examples, e.g. 〈hålegåtet〉 'begynna tala' [cf. SaaE håaledh, U hållat 'to talk'] as well as 'southern dialect” forms such as 〈håleagiet〉 'id.' corresponding to the South Saami derivative type hajkijahtjedh 'to start running'.

Other suffixes: It should be finally noted that the Saami languages, having a rich system of verbal derivational morphology for expressing lexical aspect, also employ several other derivational suffixes for expressing inchoative (beginning) aspect. In addition to the above-mentioned Pite Saami -áhtja- and similar suffixes in other western Saami idioms, commonly used suffixes include $-j-$, generalized as SaaN -á- : -áji- (vuodjit 'to drive' $\rightarrow$ vuodját $\sim$ SaaS vuajajidh 'to begin to drive'; SaaN čierrut, S tjearodh 'to cry' $\rightarrow \mathrm{N}$ čir'rot : čir'roji-, S tjyörijidh 'to begin to cry'); SaaN -iid- (golgat 'to flow, run' $\rightarrow$ golggiidit $\sim$ SaaI ku'lgijdid $\sim$ SaaP gulgijdit 'to begin to flow, run'); SaaN -(a)l- (čuoigat 'to ski' $\rightarrow$ čuoigalit $\sim$ SaaI čuoi'gâlid 'to start skiing', SaaP hudjat 'to complain' $\rightarrow$ hudjalit 'to start complaining') (Sammallahti 1989, 2007; Bergsland 1994: 92; Ruong 1943: 228, 230). These suffixes tend to be areally and lexically more or less restricted in the inchoative function, though, and usually also have other possible functions (diminutive, subitive, frequentative, conative, etc.), so the $*$-( $\breve{s})$ koate- suffix appears to be the only one which is primarily used for deriving inchoative verbs thoroughout the Saami language area. 


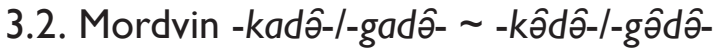

The Mordvin verb-forming derivative suffix MdE -kado-/-gado-, MdM -kadô-/-gadô$\sim-k \hat{\partial} \hat{\partial}-/-g \hat{\partial} d \hat{\partial}-$ functions primarily as a denominal translative suffix, yielding derivatives which denote changing into a quality described by the base adjective, changing into the base noun or getting covered by the base noun (Bartens 1999: 160; Hallap 2000 [1955]: 265). For example (all examples in this section from Erzya):
koźa 'rich'
koźa-kadoms 'to get rich'
ravžo 'black'
ravš-kadoms 'to blacken'
valańa 'smooth, even'
vala-kadoms $\sim$ valań-gadoms 'to become smooth, even'

These suffixes can also be found in a group of deverbal inchoative verbs (which may have a momentary or subitive nuance). Many of these have a correlate verb with $-n a-/-n a-/-n o-/-n e-$ which denote a sound and have a tinge of expressivity:

$\begin{array}{ll}\begin{array}{l}\text { avaŕ-d'e-ms 'to cry' } \\ \text { tšara-ms 'to spin' }\end{array} & \begin{array}{l}\text { avaŕ-gado-ms 'to begin to cry' } \\ \text { ťara-kado-ms: pŕam ť́arakads' 'my head began to } \\ \text { spin (swim)' } \\ \text { piže-kado-ms 'to begin to yell' }\end{array} \\ \text { piž-ńe-ms 'to yell' } & \end{array}$

In modern Mordvin languages, the suffix -kado-/gado- is highly productive as a denominal translative verbalizer (Hallap 2000 [1955]: 265; cf. the hundreds of derivatives in Luutonen \& Mosin \& Shchankina 2004: 454-464). The form variants have a distribution dependent on the preceding sound: $-k a d o$ - attaches to vowels and voiceless consonants, while -gado- attaches to voiced consonants (usually the consonant following the second-syllable vowel; the third-syllable vowel is then displaced by the suffix). The adjective suffix -na/-ńa is also left off of -kado-/gado-derivatives; cf. ŕipa-ńa 'flabby, wilted' $\rightarrow$ ripa-gadoms 'to wilt, wither'. (Hallap 2000 [1955]: 274-275.)

Derivatives with similar translative meaning are also formed with longer suffixes: 1. MdE -lgado-, M -lgâdô-; 2. MdE -śkado-, M -śkâd’̀- and 3. MdE -škado-, M $-s ̌ k \hat{d} d \hat{-}$. The suffix with preceding $l$ only attaches to vowel stems and in this position is, according to native speakers Olga Erina and Natalia Deviatkina (pers. comm.), actually the preferred translative suffix in productive use (instead of -kado-) at least

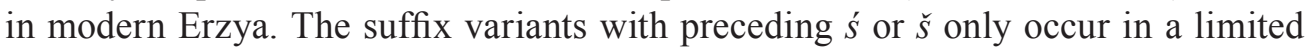
number of verbs. Examples include:

$\begin{array}{ll}\text { pśi 'hot' } & \text { pśi-lgadoms 'to become hot; to sweat' } \\ \text { ašo 'white' } & \text { ašo-lgadoms 'to become white', cf. ašola 'whitish' } \\ \text { štapo 'bare, naked' } & \text { štap-śkadoms 'to become bare, naked' } \\ \text { seń 'blue' } & \text { seń-škadoms 'to become blue' } \\ \text { (Bartens 1999: 160-161; Hallap 2000 [1955]: 283-289). }\end{array}$


The intransitive derivatives in -kado-/-gado- have transitive correlates with the suf-

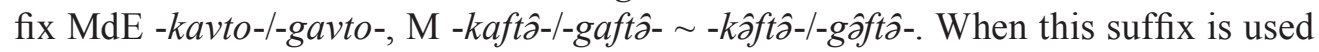
denominally, its meaning is factitive (corresponding to the translative derivatives in -kado-/-gado-), and when used deverbally, it is causative (corresponding to the inchoative derivatives in -kado-/-gado-). The suffixes with a preceding $l, s ́ s, \breve{s}$ have corresponding transitive correlates as well. Examples include:

$\begin{array}{lll}\text { koźa 'rich' } & k \text { kźakadoms 'to get rich' } & \text { koźakavtoms 'to make rich' } \\ \begin{array}{l}\text { avaŕd'ems 'to cry' } \\ \text { ašo 'white'gadoms 'to begin to cry' } \\ \text { ašolgadoms 'to become white' }\end{array} & \begin{array}{l}\text { ašolgavtoms 'to make cry' } \\ \text { white, bleach' }\end{array}\end{array}$

štapo 'bare, naked' štapśkadoms 'to become naked' štapśkavtoms 'to undress, to strip'

(Bartens 1999: 161; Hallap 2000 [1955]: 290-292).

\subsection{Veps-Ludic -gande-/-škande- -gade-/-škade-}

The derivational suffixes -gande- and -škande- occur in the whole speaking area of Veps and Ludic except for Northern Ludic, where the corresponding suffixes are -gade- and -škade-. The front vocalic variants -gände-, -škände-, etc. are rare due to weak or missing vowel harmony in these idioms. (Turunen 1973: 433.) Both derivative types have a similar conjugation:

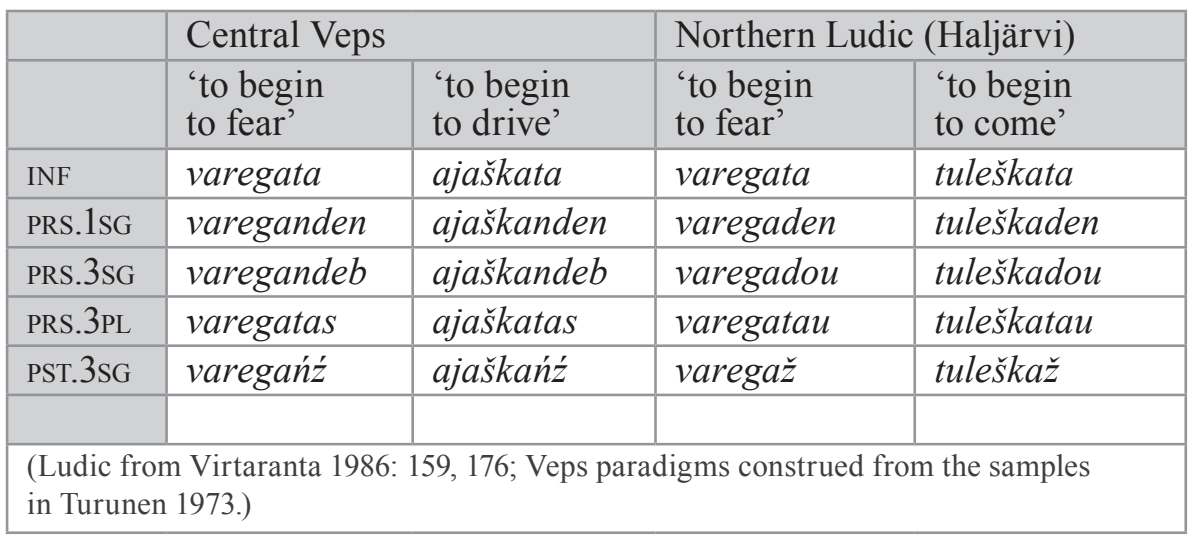

The derivatives are inchoative, denoting the beginning of the action or state expressed by the base verb. A future time reference is often implied, sometimes even as a primary interpretation (not $\bar{\imath}$ rippu aidaл, pigā rippuškandęb 'the seine net is not hanging on the fence, soon it will be hanging'; Kettunen 1943: 453). Occasionally the meaning is 'be about to' (sä i Kettunen 1943: 454).

The suffix variant with $\check{s}$ seems to be fully productive, while the $\check{s}$-less - ga(n)deis attested in a restricted number of verbs and typically attaches to verb stems ending 
with ai/äi as well as some $i$ - and $u$-stems. As a rule, the stem-final ai/äi or a/ä changes into $e$ before the suffix: varai-ta $\rightarrow$ vare-gata 'to begin to fear', heläi-dä $\rightarrow$ hele-gata 'to begin to tinkle', el'ä-da $\rightarrow$ el'e-gata 'to begin to live' (exceptions: era-gata 'to part', häda-gata 'to get alarmed'). Also, in Ludic, the stem-final $e$ usually changes into $i$ before the -škande- suffix: lähte- $\rightarrow$ lähti-škande- 'to begin to leave', ńäge- $\rightarrow$ nägi-škande- 'to begin to see'. (Turunen 1973: 431-439, cf. Tunkelo 1943: 256.)

The derivational bases for - $g a(n) d e$ - are often expressive verbs, and when not, the meanings tend to be translative as much as inchoative, and have causative correlates in -ta- or -goit(a)-. It is noteworthy that the -goit (a)- causatives, like -ga(n) $d e$ - inchoatives, cause a stem vowel change of $a(i) / \ddot{a}(i)>e$ :

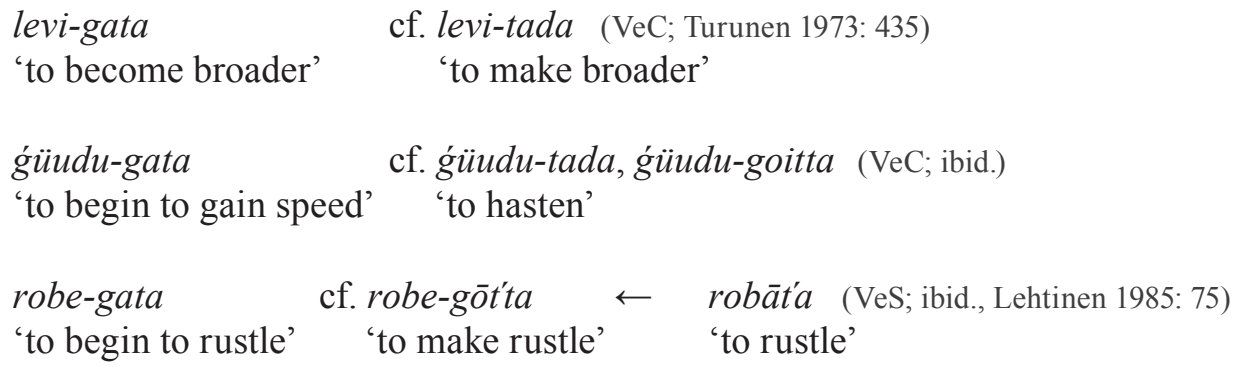

Mixing into other verbal paradigms can sometimes be observed (e.g. VeC Voilahti virigatat [pro virigandet] 'you begin to light [a fire]'; Turunen 1973: 437) as well as combinations of two inchoative suffixes (Lu Naamoila metš humegāšsaaž [hume-gaž

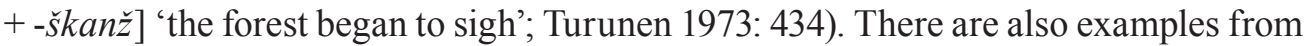
Haljärvi Ludic, where the inchoative suffix is accompanied by an automative-reflexive -u-: levi-gand-u-da 'to begin to spread', viri-gand-u-da 'to be kindled' (Virtaranta 1986: 132-133). (Note that these forms have -gand- with $n$, although the regular inchoative suffixes in this dialect are -gade-/-škade-!)

\section{History and relatedness of the suffixes}

The background and possible interrelations of the suffixes discussed here have been addressed with different kinds of explanations by previous scholars:

I. Agglutination of several suffixal elements:

a) The Veps and Ludic suffixes are based on the Finnic translative (?) element $-k a-/-k \ddot{a}$ - found in such derivatives as Livonian $\ddot{a} d \bar{a} g \tilde{o} b$ 'is alarmed' and pos-

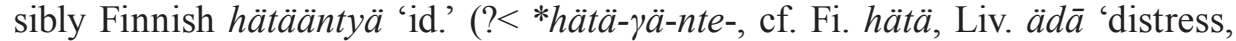
trouble'). - Setälä (1899); Posti (1942); Zajceva (1978); Lehtinen (1985).

b) The Veps and Ludic suffixes are connected to the Finnic nominalizer suffix *-ek(e), present also in Veps-Ludic adverbs such as elegil 'alive; maintained by smb.' (cf . elä- 'to live'). - Turunen (1973). 
c) The initial component of the Mordvin suffix is possibly cognate with Finnic $-k a-/-k \ddot{a}$ - found in Livonian -gõ-, Veps -gande- as well as the Mari translative

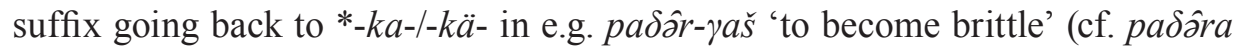
'brittle'). - Hallap (2000 [1955]).

2. Change of function:

d) The Veps suffix is originally frequentative in meaning, possibly related to the frequentative suffix -skende- $\sim$-škende-. - Kettunen $(1922,1943)$.

3. Cognation of the entire suffix:

e) The Mordvin suffix -gadâ-/-gâdô- is possibly cognate with Ludic -gade-; the longer suffix variant -śkadô-/-śk $\hat{d} d \hat{\jmath}$ - may correspond to Ludic -škade-/-škäde-. Hallap (2000 [1955]).

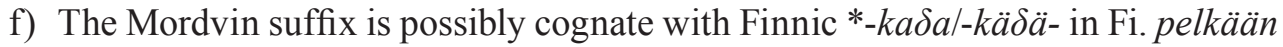

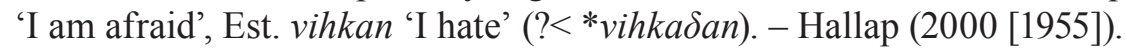

g) The Veps-Ludic and Saami suffixes are cognates (the $n$ in Veps -gande- is secondary). - Sammallahti (1977).

h) The Mordvin and Saami suffixes are cognates (?). - Sammallahti (1998).

4. Borrowing of the suffix:

i) The Veps and Ludic suffix has been borrowed from Saami. - Tunkelo (1946).

j) The Saami suffix has possibly been borrowed from Veps-Ludic. - Turunen (1973).

In the following section, I will discuss the arguments concerning different theories of origin for each suffix family. I will start with the Veps-Ludic suffixes, which have so far been the most thoroughly researched.

\section{I. The background of Veps-Ludic -gande-/-škande- -gade-/-škade-}

The Veps-Ludic inchoative suffixes -ška(n)de-, $-g a(n) d e$ - have been the subject of two in-depth articles by Aimo Turunen (1973) and Tapani Lehtinen (1985). Turunen presents an extensive collection of this type of derivatives sorted according to the stem vowel, and argues that since a frequent class of $-g a(n) d e$ - derivatives has a base verb with stem vowel $a(i) / \ddot{a}(i)$ which changes into $e$ in the derivative, the inchoative suffix has a connection to (is based on?) the nominalizer suffix -ek:*-eke-. This claim is supported by a group of adverbs formed with the said nominalizer from the same verb stems which occur in the inchoative verbs (e.g. elegil 'alive; maintained by smb.', cf. elä- 'to live' and elegata 'to begin to live'). (Turunen 1973: 436-437.) The connection with -ek(e) is, however, rejected by Lehtinen (1985: 65), who points out that only four distinct verb stems have these adverb correlates, and moreover, one would expect the inchoative suffix to contain the vowel $e$ (**-gende-) instead of $a$, if it was based on *-eke. Instead, Lehtinen supports the idea already put forward by Setälä (1899: 99-100) that the Veps -gande- is the historically primary suffix variant and contains the Finnic suffix *-ka-, which is reflected in the Livonian translative verbalizer -gõ-. The latter component would be the frequentative suffix *-nte- (cf. Veps jokse-nde- $n$ 'to run around' PRS.1sG). The original function of the combined suffix was supposedly 
that of a denominal translative verbalizer, similarly to the Livonian one, but it later got deverbal usage based on such ambiguous derivatives as tora-gata 'to begin to quarrel', cf. tora 'quarrel' or tora-ta 'to quarrel'. Translative and inchoative semantics come close to each other, as both denote some kind of a change: moving into a new state or action. (Lehtinen 1985: 66-67.)

On the basis of the Russian translations of different inchoative derivatives (mostly from Zajceva 1978 and Zajceva \& Mullonen 1972), Lehtinen concludes that the Veps -gande-derivative type has developed into its present form following the model of the Russian verbal semantic system. The -gande-verbs seem to correspond to Russian inchoative verbs with perfective aspect (usually with the prefix $z a$-). These verbs are often of expressive nature and emphasize the beginning of an action as an event of its own, in contrast to the imperfective inchoatives, which are formed with an auxiliary verb načat' or stat' and describe the beginning of an action as a phase of a longer process. The latter ones have a semantic correspondence to Veps -škande- inchoatives. Notably, the -škande- suffix and the Russian imperfective inchoative type are also fully productive, whereas Veps -gande- and the Russian perfective inchoatives are not. (Lehtinen 1985: 74-78.)

A similar development is observable in Karelian, where the reflexive, passive and translative verb suffixes -utu-/-yty- and -vu-/-vy- have been taken into an inchoative use (e.g. heleytyö 'to begin to jingle', cf. helissä 'to jingle'; kiljevyö 'to begin to squeal', cf. kiljuo 'to squeal'; elevyö 'to revive; to begin to live', cf. eleä 'to live'). Also these verbs usually have perfective inchoatives as their Russian equivalents. Many of them can be interpreted as translative as well as inchoative (cf. e.g. heleytyö with helie 'bright; clear'), and Lehtinen (1985: 73) supposes that these kinds of correlations have also led to the semantic development from translative to inchoative in Karelian. The frequent change of stem vowel into $e$ before the suffixes probably originates from derivatives based on $*_{-}-\delta a$ adjectives (helie $<*$ hele $\delta \ddot{a}$ etc.; Lehtinen 1985: 73-74). It should be added that the "satellite vowel" $e$ before the Veps -gande-suffix may at least partly have a similar background, although there are other possible factors such as the analogy of the semantically similarly change-oriented translative verbal suffix -(e)ne- and adjectival comparative suffix $-m p V$, which both also have the property of changing the preceding stem vowel alä into $e$ (e.g. Fi. kova 'hard' $\rightarrow$ kovene- 'to become hard', kovempi 'harder').

The preceding sibilant $\check{s}$ in the suffix variants -škande-/-škade- have been explained as a loan from Saami on the one hand, and as a Finnic suffixal component on the other. As it seems likely that the -gande-suffix is a Finnic-internal development, the loan hypothesis can be rejected for the part of the -škande- variant as well. For a language-internal explanation, Turunen (1973: 449-450) proposes that the $\check{s}$ originates from the conditional mood marker $-i \check{s}(i)$; the conditional stem as a base for the derivatives would also explain the occurrence of $i$ in place of the stem vowel $e$. There is, however, morphological discrepancy, for instance in the Central Veps area where the stem vowel and the $i$ are distinctly preserved in the conditional forms (punoiž 'would twist/plait', lähteiž 'would go'), but the inchoatives do not contain an $i$ (punoškandob, 
lähteškandeb) (ibid.). More importantly, the combination would be morphotactically odd - derivational, i.e. word-forming suffixes, do not attach to mood markers — and the semantic or functional motivation remains vague (Lehtinen 1985: 80). Lehtinen (1985: 80-81) offers a better explanation based on expressive-continuative verbs in -iže- (: -iš-), for example Ve. värišta : väriže- 'to tremble, shiver; to weep', which would have made a continuative(-inchoative) derivative *heliš-kande-. Semantically, these verbs are close to the base verbs of the most productive Russian $z a$ - inchoatives, and after the Russian model they would supposedly have been favored bases for derivation when the -gande-suffix was beginning to gain deverbal use. This presupposes, though, that the -gande suffix was once attached to the consonant stem, contrary to its current use. The change of the stem vowel from $e$ to $i$ before -ška(n)de-in Ludic and Northern Veps is, according to Lehtinen (1985: 81), a secondary phenomenon, based on the fact that a suffixal $\check{s}$ is regularly preceded by an $i$ (due to the sound law $i s>i \breve{s}$ ), which, for its part, regularly replaces the stem-final $e$; the sequence $e s ̌$ is thus virtually non-existent. Therefore the combination of stem-final $e+$ suffixal $\check{s}$ gets a "surfacephonemic" realization as $i \check{s}$ even if the $\check{s}$ of the suffix is historically analogical.

All in all, Lehtinen's account on the background of the Veps inchoative suffixes is reasonably well argued, and the hypothesis of the contact-induced emergence of derivational inchoatives in Veps, Ludic and Karelian is in accordance with the fact that these are the only Finnic languages with an extensive system of morphological inchoative formation and at the same time those which have had the most intensive contacts with Russian, where the aspectual inchoatives are found as established categories (cf. Lehtinen 1985: 66). A comparable sign of Russian influence is that Veps also extensively applies frequentative and momentary suffixes to express imperfective vs. perfective aspect (see Puura 2010). The combined translative suffix *-kA+nte is probably an Old Veps innovation (reflected also in Livvi huriendu- 'to begin to buzz' < *huregantu-; Lehtinen 1985: 63; cf. Setälä 1899: 86). It is not impossible that the Finnish translative derivative type hätääntyä (? $\leftarrow$ hätäänte- $<*$ *ätäyänte-, cf. Agricola 〈rupeis hätendemen〉) reflects the same ${ }^{*}-k$ Ante- suffix, which would then date back to common Northern Finnic, although these derivatives have been reconstructed with $*_{-} \delta A+n t U$ or $*_{-} \delta e+n t U$ rather than $*_{-} \gamma A+n t e$ suffixes in works after Setälä (cf. Hakulinen 1979: 279, 302). The transitive correlate type of viri-gata $\leftrightarrow$ viri-goita seems to contain the same ${ }^{*}-k a$ - element $(*-k o i t t a-<*-k a+i t t a-) ;$ the transitive type also occurs in Votic, e.g. sõizagoittaa 'to bring to a stop' $\leftarrow$ sõisõa 'to stand' (cf. Setälä 1899: 88). The original short Finnic translative *-kA- reflected in Livonian ädāgõb 'is/becomes alarmed' (?*hätä-kä-pi), vīegõb 'is angry, sulks' (?*viha-ka-pi) may also have cognates in Mari translative $-\gamma a-$ and the initial part of

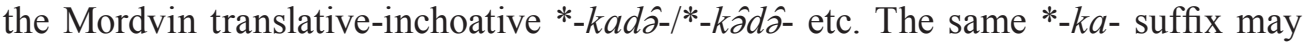
also be reflected in the Saami translative suffix -gi-t, e.g. SaaN bahčagit 'to become bitter' $\leftarrow$ bahčča 'bitter' $\left(<*_{-n k}\right.$ - ? $<$ Pre-Saami *-m(i)+kA-).

The Northern Ludic suffix variant -gade- clearly represents a secondary development based on the consonant stem forms of the paradigm: the regular -gande-paradigm forms PRS.3PL varegatau, INF varegata 'to begin to fear' are formally parallel to 
e.g. PRS.3PL laygetau, INF laygeta 'to fall (down)', from which we get PRs.1sG laygeden, PRS.3SG laygedou as an analogical model for PRS.1SG varegaden, PRS.3SG varegadou. Even in some -gade-dialects, the $n$ is still preserved in past tense forms such as varegańž 'id.' PST.3SG (Turunen 1973: 450). The opposite assumption of -gade- being the original form and -gande- being analogical (Sammallahti 1977: 192) is not plausible, considering the wide coverage of -gande- in Veps-Ludic dialects in comparison to -gade-in the compact Northern Ludic area, and the apparently sporadic nature of the cited examples of secondary $-n$ - such as rubeta : rubendab pro rubedab 'to begin' INF : PRS.3SG. ${ }^{8}$

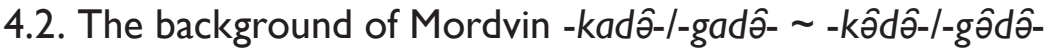

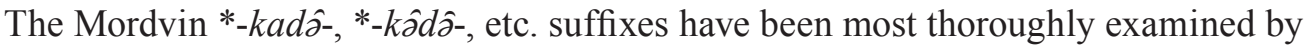
Hallap (2000 [1955]) in his study of Mordvin verbal derivation. The main dialectal

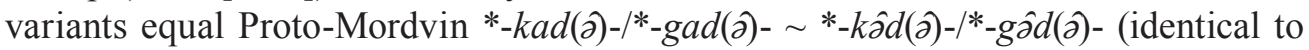
modern Moksha forms). The variants can be reconstructed as Pre-Mordvin *-kati-, or possibly *-kata- ${ }^{9}$ which would regularly result in the Proto-Mordvin suffixal vowel combination $a-\hat{\partial}$ after second-syllable PMd. * $\hat{\partial}$ and $\hat{\partial} \hat{\partial}$ after second-syllable *a (cf. Hallap 2000 [1955]: 55, 277-278; Bartens 1999: 69-70; Ravila 1929: 119). Different vowel variants would then have been generalized in different dialects.

As the Ludic -gade-/-gäde-suffix is clearly a product of late analogy, its etymological comparison with the Mordvin suffixes can be rejected. Also the comparison with Estonian vihkama 'to hate' and salgama 'to hide, keep secret' is dubious, since these verbs probably do not go back to Proto-Finnic *-ka $\delta a$-, but got their $\mathrm{k} / \mathrm{g}$ in an analogical shift to a gradation paradigm (other Finnic idioms have equivalents of Finnish vihaa-, salaa-); Fi. pelkää- 'to be afraid' might be the only verb actually reconstructable to Proto-Finnic $*_{-} k a \delta a-/-k \ddot{a} \delta \ddot{a}-{ }^{10}{ }^{10}$ and even here the suffix has no clear function in relation to the underived verb (cf. e.g. North Saami ballat 'id.' <

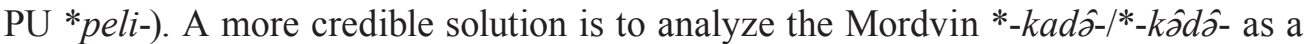

8. For example, in Kettunen's Veps and Ludic lexical materials (VVS), there are 60 entries of verbs with conjugation -ta : -ndan (of 28 distinct verbs, from 9 localities), including no single instance of an apparent paradigm shift from -ta : -dan. The conjugation data of the -ta : -dan verbs (164 entries) also contain no indication of such variation. Neither does Tunkelo mention this kind of developments in his extensive treatment of Veps historical phonology (1946: esp. 362ff.).

9. Like Hallap (2000 [1955]: 278) notes, *-kata- after second-syllable *a would strictly, according to Ravila's (1929: 119) rule, become *-kâda-, but parallel cases for preserved fourth-syllable suffixal *a

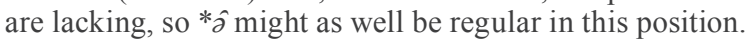

10. Another candidate is Fi./Ing. perata : perkaa- 'to clean (fish, berries); to clear (forest); to weed' ?Est. dial. (Wiedemann) põrata : põrgan, though the Kar. perkoa, Lu. pergada forms reflect the suffix

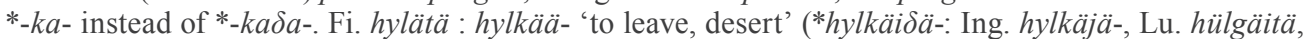

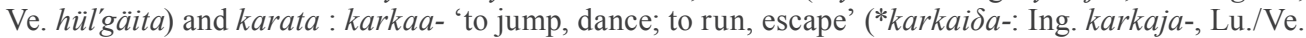

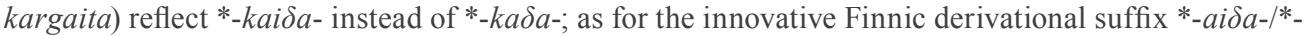
$\ddot{a} i \delta \ddot{a}$-, see Lehtinen (1979). Fi. (mostly eastern dial.) selätä : selkää- 'to search the nets without drawing them in; to repair the top ("back") of a fence, etc.' derives its -kä- element from the base noun selkä 'back'. (Distributions and meanings from SSA and SKES s.v. selkä.) 
compound suffix, where the initial component is equal to Livonian translative -gõand the initial part of Veps -gande- (<PU $\left.*_{-} k a-/-k \ddot{a}-\right)$ as well as their possible cognate suffix in Mari (cf. Hallap 2000 [1955]: 279; Lehtinen 1985: 64). The latter component would then stem from one of the widely and diversely used Mordvin verb derivational suffixes MdE -do-/-d'e-, M -dלे-/-d's- (< PU *-te-) or MdE -da-/-d'a-/-do-/-d'e-, $\mathrm{M}-d a-/-d^{\prime} a-/-d \hat{\jmath}-/-d^{\prime} \partial-(<\mathrm{PU} *-t a-/-t \ddot{a}-)$ (Hallap 2000 [1955]: 101-122, 282).

In this compound suffix scheme, we still have a couple of phonological peculiarities to explain. Firstly, the suffix-initial $* k$ should by regular sound laws have been developed into a Proto-Mordvin fricative $(v$ or $j$ ) intervocalically, but instead we have $-k$-after vowel stems. This could be explained as analogy to the regular suffix variant after a voiceless consonant; possibly there was an attempt to keep the suffix distinct from the frequent (reflexive-passive) $-v \mathrm{~V}$ - and (frequentative) $-j \mathrm{~V}$ - derivational suffixes. Secondly, the Pre-Mordvin suffix *-kati- or *-kata- would supposedly have had

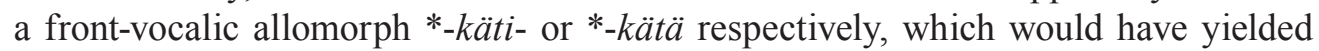

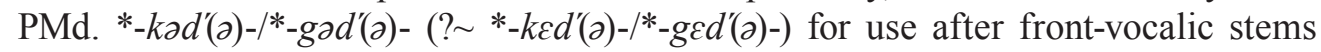
and palatalized consonants, in accordance with the usual Proto-Mordvin vowel harmony. Still, only back-vocalic allomorphs of this suffix occur, ${ }^{11}$ which is quite unique;

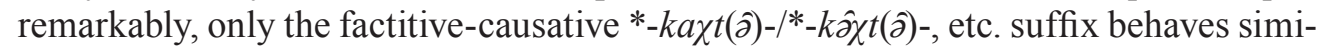
larly (cf. Hallap 2000 [1955]: 276, 290-292). ${ }^{12}$ A Proto-Mordvin leveling in favor of the back-vocalic variants must thus be assumed.

The phonotactic peculiarities mentioned above could be seen as an indication of an alternative origin of the suffix, namely, suffixation from an independent, backvocalic verb. To explain both of these peculiarities, the suffixation process would then not have been fully undergone at the time of the fricativization of intervocalic $* k$, but would have been developed far enough at the time of the suffixal $* a>\hat{a}$ change to account for the vowel variants (cf. Hallap 2000 [1955]: 282-283). It is not clear whether this scheme is chronologically viable. On the other hand, there is such a strik-

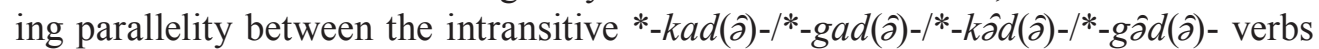

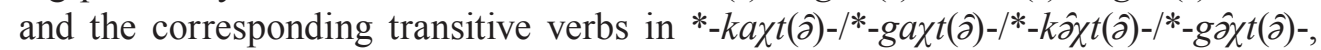
the latter of which most probably go back to a combined suffix from Pre-Mordvin

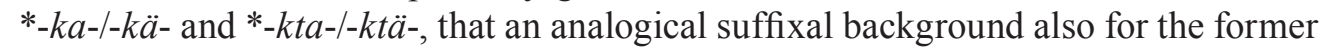
seems likely (Hallap 2000 [1955]: 283, 293). ${ }^{13}$ Also, no such independent verb has been

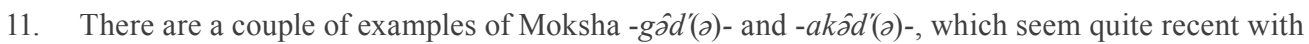
their mixed vocalism. If MdM śérǵcd'ams, E s'érǵed'ems 'to cry out; to call' contains the same suffix, this would be a unique example of a suffixal element with PMd. *c (cf. Hallap 2000 [1955]: 271, 274, 276-277). Another case might, though, be MdM pšḱcd'sms p pošḱk.d'ams, E pškad'ems, etc. 'to utter, say', provided that this represents the same derivative as E piškadoms and pižakadoms 'to cry out, shout', cf. E pižnems 'to shout'.

12. There is also at least one Common Mordvin suffix which uniformly has a front-reduced vowel independent of the phonological environment: the frequentative *-šz- (Hallap 2000 [1955]: 235-236).

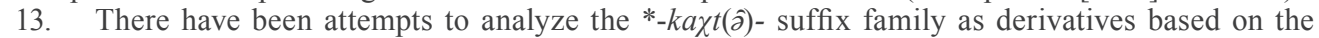
$*_{-} k a d(\hat{\partial})-$ verbs, but the assumed development in lines of $*_{-} k a d+*_{-} \chi t \hat{\partial}>*_{-} k a t \chi t \hat{\jmath}->*_{-} k a \chi t(\hat{\partial})-$ would be totally unexpected, since the consonant cluster -t $\chi t$ - has in other words either been preserved (in some Erzya dialects) or developed into - tft- (in Moksha) or -st- (in other Erzya dialects) (Hallap 2000 [1955]: 293). 
pointed to which would be both phonologically and semantically a suitable source for the assumed suffixation. The verb kadoms 'to leave (behind)' would fit phonologically, but it would not be semantically plausible to assume it to be the primary source of the translative-inchoative suffix family, since the suffixed verbs are intransitive whereas kadoms is a transitive verb, like the majority of its underived cognates (e.g. SaaN guođđit, Mari koঠem, Hung. hagy 'id.'; cf. SSA s.v. kadota). At the most, we could perhaps suppose that certain uses of the verbs MdE kadoms, M kadams 'to leave' and E kadovoms, M kadəेvâms 'to be left' have had a supporting analogical influence to the establishing of the post-vocalic *-kadô- suffix variant; cf. e.g. E čavo kadoms 'to leave empty, deserted', čavo kadovoms 'to be left empty, deserted' and štapokadovoms $\sim$ štapo kadovoms 'to get naked; to be left naked' (MdWb s.v. čavo, štapo).

As for the origins of the suffix variants -lgado-/-śkado-/-škado-, the initial consonants have probably been abstracted from base stems with $-l,-s,-\check{s}$, such as MdE $a \check{s} o$ 'white', ašola 'whitish' $\rightarrow$ ašolgadoms 'to become white(r)', M valaźa 'slippery' $\rightarrow$ valaśkâdâms 'to become slippery' and E sijaža 'silvery' $\rightarrow$ śijaškadoms 'to become silvery’ (Hallap 2000 [1955]: 285; Bartens 1999: 160-161).

\subsection{The background of Saami -(̌̌)goahti-}

As the inchoative verb derivation suffix SaaN -goahti- and its cognates are found in all current Saami languages, the suffix can justifiably be derived from Proto-Saami (*-koate-). Above we have concluded that the Veps-Ludic translative-inchoative suffixes -gande-, -škande-, etc. are the result of semantic recategorization of a suffix cluster, carried out in the Vepsian branch of Finnic under the influence of Russian. Against this background, the possible Vepsian loan origin of the Saami - $(\breve{s})$ goahti- suffix (proposed by Turunen 1973: 450) can be excluded on chronological grounds: According to current datings, the dispersal of Proto-Saami to the current Saami-speaking areas must have taken place during the first centuries CE, whereas the independent development of the Ladogan, and consequently the Vepsian branch of Finnic did not begin until ca. 700 CE, and neither did the Slavic contacts (Aikio 2012b: 104; Kallio 2014: 164-165). The connection is also phonologically poorly justified. Chronologically there is a slight possibility that the eastern Saami $-\check{s}$ - element could partly reflect early Vepsian influence on eastern Saami idioms that were once located further south in the neighborhood of the Veps, but the borrowing of this kind of a co-affix would in practise presuppose the borrowing of larger items, derived lexemes in the first place, of which we have no evidence in this case.

Sammallahti (1977) has proposed that the Saami and Veps-Ludic inchoative suffixes go back to a common Pre-Saami-Finnic form *-(s)kota-. To achieve the common reconstruction, he assumes that the Ludic - $(\check{s})$ kade-suffix is primary and the Veps-Ludic - $(\check{s})$ kande- is secondary, citing other cases of secodary, analogical $n$ in Veps such as rubeta : rubendab (pro rubedab) 'to begin' INF : PRS.3SG. In this case, however, it is far more likely that the $n$-less forms are secondary, since they only 
occur in Northern Ludic, where the $n$ can still be observed e.g. in past tense forms such as varegańž (see above). As to the vowel correspondence, Sammallahti refers to the group of words exhibiting Saami $o a-\bar{e} \sim$ Finnic $a-e$, such as SaaN čoalbmi $\sim$ Fi. salme- 'sound, strait', which Aikio (2015) has recently shown to be a regular correspondence of words in PU $* a-i$. The hypothetical (West-)Proto-Uralic suffix would then be *-kati-. As the consonantism of the Veps-Ludic suffixes cannot be credibly derived from this form and there is another, formally and semantically satisfactory explanation for them involving the Finnic suffixes $*-k a-/-k \ddot{a}$ - and -nte-, we should dismiss the reconstruction for the part of Veps-Ludic. The Mordvin translative-inchoative suffixes $*_{-} k a d(\partial \hat{)})$, $*_{-} k \partial d(\hat{\partial})-$, etc. can, however, be reconstructed to PU *-kati(/-käti-?) or possibly *-kata-(/-kätä-?), with the reservations discussed in Section 4.2. Sammallahti later (1998: 92) revised his reconstruction of the Saami suffix to FinnoVolgaic $(\approx$ West-Uralic) *-kata-/-kätä- (without further explanation), which points to an etymological equation with the Mordvin suffix family treated here. That reconstruction is, however, incompatible with the phonological shape of the Saami suffix, both in the traditional and in Aikio's framework. Thus, *-kati- would be a tentative common reconstruction for the Saami and Mordvin suffixes, but not an unproblematic one.

The main problem in analyzing SaaN -goahti- as a descendant of a (West-)ProtoUralic suffix lies in its phonotactics: the diphtong oa does not otherwise occur in non-initial syllables of current Saami languages. If there was a supposed Pre-Saami $*_{-k a t i-}$ as a normal suffix, we would expect developments such as *meni-kati-m> PSaa. *meñegāoem > *meñegeadem > SaaN **mannageađan 'go-INCH-1sG'. A suffixal labial vowel would not yield $o a$ either in modern Saami. The Proto-Saami noninitial long labial vowel, (Middle) Proto-Saami *j, has in the unstressed second syllable developed into $\bar{o}$ or further $u o$ or $u(\operatorname{SaaN} u)$ in other Saami varieties except for Skolt and Kola Saami and the southmost South Saami, where it has been illabialized into $\bar{a}$ (Sammallahti 1998: 24, 29). In a secondary-stressed position, usually the third syllable, the vowel has remained long $(u o)$ in southern South Saami and shortened to $u$ in other idioms (e.g. SaaS [S] baanahtoevedh $\sim[\mathrm{N}]$ baanahtovvedh, SaaL báneduvvat,

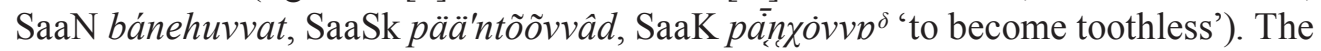
only bound morphem, which has a secondary-stressed uo in all Saami languages, is the adjective-nominalizer SaaN -vuohta (<PSaa. *-vuote), which is customarily taken to be an affixated loan from Proto-Finnic *vuote ( $>$ Fi. vuosi 'year'). ${ }^{14}$ The Saami suffixes -goahti- and -vuohta share the phonotactic peculiarities that they always take the secondary word stress on their first syllable and have an abnormal labial diphtong in that position, which is why they have often been described as compound-like elements, despite their otherwise suffix-like behavior (e.g. Nielsen 1979 [1926]: 248, Lehtiranta 1992: 29-30). Historically, this is most naturally explained by

14. Alternatively, the source of affixation could be an inherited word reflected as an independent word in South Saami voete 'manner, way' and East Khanty ot 'thing, matter' (Aikio 2012a: 234 footnote). 
assuming both to reflect an agglutinated lexical item whose affixation process is in an intermediate stage where they still possess some properties of independent lexemes. Affixation is a standard process of the development of suffixes in languages, and although there are some rare examples of an opposite process of suffixes developing into independent words, e.g. the SaaN abessive haga 'without' (see Ylikoski 2016), it would definitely be odd if this kind of degrammaticalization process were to start with developing phonological features otherwise forbidden in a suffixal position.

Thus, if the -goahti- suffix goes back to an independent word, we should point out the concrete item. A phonologically fully-corresponding verb stem (PSaa. *koate$\sim$ PU *kota-/*kati-) has not been indicated, but Ylikoski (2009: 127) has briefly proposed that the source might be SaaN boahtit (<PSaa. *poate-) 'to come'. ${ }^{15}$ The semantic connection between 'coming' and 'beginning' is rather clear (cf. e.g. English come to know); the shift of meaning from 'movement' to 'beginning' has been recorded for instance in English start 'to begin' < 'to leap (into something)', Latin initium 'beginning' < 'entrance' $\leftarrow$ in- 'in(to)' + ire 'to go'. The phonological shape, however, needs further explanation concerning the initial consonant. A spontaneous change of $p$ to $k$ is not entirely impossible, since both are voiceless stops and differ only in terms of the place of articulation, but the $k$ might well have a material source in a former construction involving the infinitive of the content verb before boahti-. For example:

\begin{tabular}{|c|c|c|c|}
\hline $\begin{array}{l}*_{s u k e-D e} k \\
\text { row-INF }\end{array}$ & $\begin{array}{l}\text { poad } \bar{a}-m \\
\text { come-1sG }\end{array}$ & $>$ & $\begin{array}{l}\text { *suke }(-D V)-k o a D \bar{a}-m \\
\text { row-INCH-1sG }\end{array}$ \\
\hline 'I come to & & & \\
\hline
\end{tabular}

This presupposes that the favored word order at the time of the affixation was still the Uralic verb-final type, which actually seems to have been the case even long after the break-up of Proto-Saami, since both modern South Saami and $18^{\text {th }}$-century North Saami (Porsanger/Karasjok dialect according to Leem 1748) still show SOV basic word order (Magga 2003: 35; Kemi 1994: 61). There are no parallels of the development of a cluster $* k p$ in Proto-Saami, but it seems entirely possible that it would have been simplified to $* k$ in a suffixation process, along with the reduction of the rest of the original infinitive ending *-tek . The reduction and loss of the unstressed third syllable between a bisyllabic verb stem and the still (secondarily) stressed bisyllabic suffixoid seems quite natural, since the Saami languages show a strong preference of word forms consisting of bisyllabic stress groups especially in verbal conjugation (Korhonen 1981: 259-260), and the original infinitive ending does not carry any significant function in the agglutinated construction. This explanation goes well together with the fact that inchoatives with plain ${ }^{*}$-Goat $\bar{e}$ - only take parisyllabic base verbs in all Saami varieties.

15. Saami *poate- 'to come' itself lacks an etymology beyond Proto-Saami. In the vowel-historical framework of Aikio (2015), the verb stem could be reconstructed to PU *pati- and connected to Fi. patikka 'a journey on foot', patikoida 'to walk' and pade 'path'. On the other side, the Finnish words can also reflect a Germanic loanword ( $\leftarrow$ Proto-Germanic *pap-, cf. German Pfad 'path') (SSA s.v. pade). 
The co-affix š in -šgoahti- needs its own explanation. Sammallahti (1977) proposes that it might either be a Vepsian loan element, which we already found dubious,

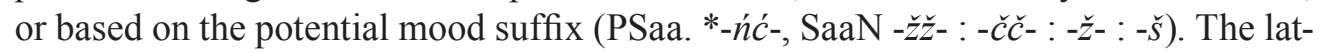
ter explanation faces the same difficulty as Turunen's conditional mood explanation for Veps: the morphotactics does not allow a mood marker to be followed by a derivational suffix. Nor does it seem plausible that a finite verb form in potential mood would have been used adverbially in constructions like that above. Most likely the $-\check{s}$ element has been generalized from verb stems which themselves have been derivatives containing $\check{s}$ or a consonant (cluster) later reduced to $\check{s}$; cf. Lehtinen's explanation for Veps-Ludic-ška(n)de-above. A possible source would then be in the verbs with the diminutive-frequentative suffix SaaN -aš- $(<$ PSaa. *-ehče- $<*$-ekče $-\sim$ Fi. frequ. -(e)kse-) as in attašit 'to give a little at a time' $\leftarrow$ addit 'to give' (cf. Korhonen 1981: 337; Sammallahti 1998: 92; LpD s.v. âddâšit). The above-mentioned suffix would also phonologically match the inchoative suffix variant with an affricate in Pite Saami -atjgåhte-, and Ruong (1943: 219-222) actually analyzes SaaP -atjgåhte- as a combination of two inchoative suffixes, -áhtja- and -gåhte- (báhkad-áhtja-t $\rightarrow$ báhkadatj-gånte-t, both 'to begin to get warm'). In Lule and South Saami there is a similar inchoative suffix -ahtj- with a short $a(<*)$ in the third syllable, e.g. SaaL aled-ahtjat 'to begin to raise' $\leftarrow$ aledit 'to raise', SaaS valkes-ahtjedh 'to begin/prepare to set off' $\leftarrow$ valkesidh 'to set off' (O. Korhonen 2007; Bergsland 1994: 92), which is phonologically equal to the expected secondary-stressed form of the diminutive-frequentative suffix mentioned above (PSaa. *-ehče- : -ekčes-) and can be thought of as a functionally differentiated variant of the same suffix (as a parallel, compare the instances of other Saami diminutive and frequentative suffixes in an inchoative function, e.g. SaaN vázzilit, S vaedtsielidh 'to start going, to go away'; N biekkastit, S biegkestidh 'to begin to blow [wind]'). The Ume and Pite Saami -áhtja- suffix is probably historically identical with these, except that the short $a$ in the secondary-stressed third syllable has been replaced with long $a$, possibly due to an association with another inchoative suffix -á(j)- occurring in the unstressed second syllable (e.g. SaaP jåhttát 'to begin to move' $\leftarrow$ jåhtet 'to move, migrate').

It is thus possible that an inchoative suffix based on PSaa. *-ehče- : *-ekčewas once used in the whole Saami area, but later it was functionally replaced by the phonologically and semantically more distinct $*_{- \text {Goate }}$, and additionally amalgamated with it (*-ekče-Goat $\left.\bar{e}^{-}\right)$in certain Saami varieties. The rise of this combined suffix was clearly motivated by syllable structure, as it originally attaches to trisyllabic stems: the general preference of Saami languages towards word-forms consisting of bisyllabic stress groups made e.g. *pekè $\mid$ Dekče $\mid$ Goatà 'begins to get warm' more favorable than *pekeve Goata (from *peke-De- 'to get warm'; borders of stress groups marked here with '|'). The phonological reduction of the combined suffix to $*_{-} c k$ oat $\bar{e}-\sim *_{-s}$ koat $\bar{e}-$ later diminished the syllable-structural difference in compari-

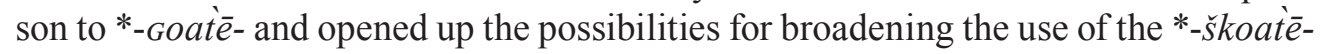
suffix also to parisyllabic stems, which has happened in eastern Saami. The weak grade stem in eastern Saami derivatives such as SaaSk looggškue'tted thus most 
likely reflect an analogical adaptation of $*_{-}-s k a t \bar{e}-$ to the gradation pattern of other

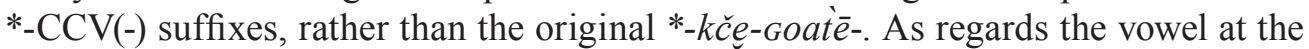
border of the stem and the suffix, it seems that Lule and Pite Saami maintained their association with the -álahtja-inchoative, while North and eastern Saami generalized $i$ as the third syllable vowel by analogy with the infinitive stem (cf. SaaN bahkadit 'to get warm' $\rightarrow$ bahkadišgoahtit 'to begin to get warm').

\section{Conclusions and discussion}

The current paper has discussed the variation and history of phonologically similar derivative suffixes with inchoative and partly translative functions in three western Uralic language branches - Saami, Mordvin and the Veps-Ludic sub-group of Finnic - with a special focus on the Saami -(̌́s)goahti- suffix. The suffixes in question have in previous literature been connected with varying historical interpretations and combinations as either etymological cognates or loan items. The current survey shows, however, that each suffix has its own development history within its language branch, and that only some etymologically connectable components can be identified (Mordvin-Finnic *-ka-/-kä-), as well as common tendencies in the semantic-functional development of derivational suffixes, such as the change from translative to inchoative or frequentative to inchoative. Specifically, it was argued that the Saami -goahti- suffix is a result of the affixation of an independent verb (*poate- $>$ North Saami boahtit 'to come'), and the -š- element in -šgoahti- is a remnant of another frequentative/inchoative derivational suffix (*-ehče- : *-ekče- > SaaN -aš-, SaaP -atj: -áhtja-). Judging from the distribution comprising all known Saami varieties, the inchoative suffix *-Goatè- developed in common Proto-Saami; a grammatical morpheme would hardly have reached such an extensive coverage through later dialectal diffusion. The combined inchoative suffix *-ekče-Goatè- (> SaaP -atjgåhte-, SaaN -(i)šgoahti-) was probably a somewhat later innovation, excluding the proto-dialect of South (and Ume) Saami, and was motivated by syllable stress structure. The use of the combined suffix, originally limited to trisyllabic stems, was then generalized in eastern Saami to bisyllabic stems as well; the innovation seems to be relatively late, since it has still only started to spread into Ter Saami.

It can be further noted that the -ahtja- inchoative suffix appears in precisely those Saami languages, South Saami through Lule Saami, which lack the historically identical *-kče- conditional marker. The background of this complementary distribution can be explained in several ways: as parallel developments based on the supposedly primary diminutive/frequentative function of the suffix, or as the receding of one of the homophonous categories as the other one gained popularity. As certain features of the western Saami $-l$ - conditional have been explained as analogical effects of the supposedly older $*_{-} k c$ - conditional (Korhonen 1981: 255), a plausible scenario could be that the advent of the -ahtja-inchoative in western Saami gave an impetus to the replacement of the homophonous but semantically incompatible 
conditional marker in a secondary-stressed position — and later everywhere - with a novel conditional marker based on the $-l$ - frequentative suffix. ${ }^{16}$ True, the broad distribution of the $*_{\text {-čkoate }}$ - inchoative would also suggest an early origin for the *-ekče- inchoative, but as a matter of fact, the main function of the first part of the combined suffix need not have been inchoative at the time of the establishment of the suffix complex. Another sign of an attempt to minimize the number of different functions of the secondary-stressed *-ekče- suffix is that it is severely marginalized as a variant of a diminutive or frequentative suffix. As such, it is found only in eastern Saami (Korhonen 1967: 136-137), and even there it seems to appear only in combination with the -l-frequentative suffix, as SaaI -lâhčâ- $\sim-l u h c ̌ a ̂-\sim$ Sk -lõóčč $\hat{a}$ - (material of InLpWb and Sammallahti \& Mosnikoff 1991). ${ }^{17}$ The situation also resembles the areal-functional distribution of the cognate Finnic suffix $-k s(e)-\rightarrow-k s i-$, which only acts as a frequentative suffix in northern Finnic (Fi. ole-ksi-n 'to be'-FREQ-1SG), while in southern Finnic it has developed into a conditional mood marker (Est. ole-ksi- $n$ 'to be'-COND-1SG) and lost the frequentative function completely.

16. According to an alternative explanation by Sammallahti (1998: 83 ), the - $l$ - conditional stems from the combination of a present tense marker $*_{-} k$ and the contracted past tense of the copula verb, * $l i$ - (i.e., $\left.*_{-k l i-}>*_{-} v l i-\right)$. While this would formally explain the $-v$ - element (SaaL málestivlum 'I would cook') and the weak-grade stem (SaaN [west] oađálin 'I would sleep'), the functional and morphosyntactic motivation of such a construction remains vague.

17. A few of these derivatives have an inchoative meaning, but this is clearly inherited from the corresponding -l- derivative, e.g. SaaI vázzálâhčâđ ‘hin- und hergehen; zum Spaziergehen aufbrechen' $\leftarrow$ väzzilid 'losgehen, zu Fuss aufbrechen '; Sk vä'zzlõõččâd = vä'zzled 'to set off walking.' 


\section{Abbreviations of languages}

$\begin{array}{llll}\text { Est. } & \text { Estonian } & (\mathrm{Saa}) \mathrm{N} & \text { North Saami } \\ \text { Fi. } & \text { Finnish } & (\mathrm{Saa}) \mathrm{P} & \text { Pite Saami } \\ \text { Hung. } & \text { Hungarian } & (\mathrm{Saa}) \mathrm{S} & \text { South Saami } \\ \text { Ing. } & \text { Ingrian (Izhorian) } & (\mathrm{Saa}) \mathrm{Sk} & \text { Skolt Saami } \\ \text { Kar. } & \text { Karelian } & (\mathrm{Saa}) \mathrm{U} & \text { Ume Saami } \\ \text { Liv. } & \text { Livonian } & \mathrm{Sk}(\mathrm{P}) & \begin{array}{l}\text { Paatsjoki dialect of Skolt } \\ \text { Lu. }\end{array} \\ \text { Ludic } & & \text { Saami } \\ \text { (Md)E } & \text { Erzya (Mordvin) } & \mathrm{Sk}(\mathrm{S}) & \text { Suõ'nn'jel dialect of Skolt } \\ \text { (Md)M } & \text { Moksha (Mordvin) } & & \text { Saami } \\ \text { PMd. } & \text { Proto-Mordvin } & \mathrm{Sk}(\mathrm{N}) & \text { Nuõ'ttjäu'rr dialect of Skolt } \\ \text { PSaa. } & \text { Proto-Saami } & & \text { Saami } \\ \text { PU } & \text { Proto-Uralic } & \text { Ve. } & \text { Veps } \\ \text { (Saa)I } & \text { Inari Saami } & \text { VeC } & \text { Central Veps } \\ \text { (Saa)K } & \text { Kildin Saami } & \text { VeS } & \text { Southern Veps } \\ \text { (Saa)L } & \text { Lule Saami } & & \end{array}$

\section{Grammatical glosses}

$\begin{array}{llll}1 & 1^{\text {st }} \text { person } & \text { INF } & \text { infinitive } \\ 3 & 3^{\text {rd }} \text { person } & \text { PL } & \text { plural } \\ \text { COND } & \text { conditional } & \text { PRS } & \text { present } \\ \text { FREQ } & \text { frequentative } & \text { POT } & \text { potential } \\ \text { IMP } & \text { imperative } & \text { PST } & \text { past } \\ \text { INCH } & \text { inchoative } & \text { SG } & \text { singular }\end{array}$

\section{References}

Aikio 2012a = Luobbal Sámmol Sámmol Ánte (Ante Aikio): On Finnic long vowels, Samoyed vowel sequences, and Proto-Uralic *x. - Tiina Hyytiäinen \& Lotta Jalava \& Janne Saarikivi \& Erika Sandman (eds.), Per Urales ad Orientem. Iter polyphonicum multilingue. Festskrift tillägnad Juha Janhunen på hans sextioårsdag den 12 februari 2012. MSFOu 264. 227-250.

Aikio 2012b = Luobbal Sámmol Sámmol Ánte (Ante Aikio): An essay on Saami ethnolinguistic prehistory. - Riho Grünthal \& Petri Kallio (eds.), A linguistic map of prehistoric Northern Europe. MSFOu 266. 63-117.

Aikio, Ante 2015: The Finnic 'secondary e-stems' and Proto-Uralic vocalism. - JSFOu 95: 25-66.

Barruk, Henrik 2018: Báhkuogirjjie: ubmejesámien-dáruon, dáruon-ubmejesámien. / Ordbok: umesamisk-svensk, svensk-umesamisk. Umeå: Kanaanstiftelsen i Sverige.

Bartens, Raija 1999: Mordvalaiskielten rakenne ja kehitys. MSFOu 232.

Bergsland, Knut 1994: Sydsamisk grammatikk. [Karasjok:] Davvi Girji.

Bergsland, Knut \& Magga, Lajla Mattsson 1993: Aarjelsaemien-daaroen baakoegcerja. Sydsamisk-norsk ordbok. [Lakselv:] Iđut. 
Bussmann, Hadumod 1996: Routledge dictionary of language and linguistics. Translated and edited by Gregory Trauth and Kerstin Kazzazi. London - New York: Routledge.

Bybee, Joan L. 1992: Tense, aspect, and mood. - Bright, William (ed.), International encyclopedia of linguistics vol. 4. New York - Oxford: Oxford University Press. 144-145.

Collinder, Björn 1949: The Lappish dialect of Jukkasjärvi. A morphological survey. Skrifter utgivna av K. Humanistiska Vetenskaps-Samfundet i Uppsala 37:3. Uppsala: Almqvist \& Wiksell.

Crystal, David 1997: Dictionary of linguistics and phonetics. $4^{\text {th }}$ edition. Oxford: Blackwell.

Fiellström, Petrus 1738: Grammatica Lapponica. Holmiae.

Ganander, Henricus 1743: Grammatica Lapponica. Holmiae.

Grundström, Harald 1946-1954: Lulelapsk ordbok / Lulelappisches Wörterbuch 1-4. På grundval av K. B. Wiklunds, Björn Collinders och egna uppteckningar utarbetad av Harald Grundström. Skrifter utgivna genom Landsmåls- och Folkminnesarkivet i Uppsala, Ser. C:1. Uppsala.

Hakulinen, Lauri 1979: Suomen kielen rakenne ja kehitys. 4., korjattu ja lisätty painos. Helsinki: Otava.

Hallap, Valmen 2000 [1955]: Verbaaltuletussufiksid mordva keeltes. Eesti Keele Instituudi toimetised 5. Tallinn: Eesti Keele Instituut.

Hasselbrink, Gustav 1981-1985: Südlappisches Wörterbuch I-III. Skrifter utgivna genom Dialekt- och Folkminnesarkivet i Uppsala, Ser. C:4. Uppsala.

InLpWb = Itkonen, Erkki 1986-1991: Inarilappisches Wörterbuch. 1-4. LSFU 20.

JSFOu = Journal de la Société Finno-Ougrienne. Helsinki.

Kallio, Petri 2014: The diversification of Proto-Finnic. - Ahola, Joonas \& Frog \& Tolley, Clive (eds.), Fibula, fabula, fact. The Viking Age in Finland. Studia Fennica Historica 18. Helsinki: Finnish Literature Society. 155-170.

Kemi, Kjell 1994: 1700-jagiid Leavdnjavuona suopman. - Dieđut 2/1994 (Giellačállosat II). Guovdageaidnu: Sámi Instituhtta. 32-91.

Kettunen, Lauri 1922: Lõunavepsa häälik-ajalugu 1. Acta et Commentationes Universitatis Dorpatensis B II, 2. Tartu.

Kettunen, Lauri 1943: Vepsän murteiden lauseopillinen tutkimus. MSFOu 86.

Kintel, Anders 1991: Syntaks og ordavledninger i lulesamisk. Kautokeino: Samisk utdanningsråd.

KKLS $=$ T. I. Itkonen 1958: Koltan- ja kuolanlapin sanakirja. Wörterbuch des Kolta- und Kolalappischen. I-II. LSFU XV. [Available at http://www.sgr.fi/lexica/lexicaxv.html ]

Korhonen, Mikko 1967: Die Konjugation im Lappischen. Morphologisch-historische Untersuchung. I. Die finiten Formkategorien. MSFOu 143.

Korhonen, Mikko 1981: Johdatus lapin kielen historiaan. Helsinki: Suomalaisen Kirjallisuuden Seura.

Korhonen, Olavi 2007: Báhkogirjje. Julevusámes dárrui, dáros julevusábmái. Lulesamisk svensk, svensk lulesamisk ordbok. Jokkmokk: Sámij åhpadusguovdásj.

Lagercrantz, Eliel 1929: Sprachlehre des Nordlappischen nach den seelappischen Mundarten. Oslo: Oslo Etnografiske Museum.

Leem, Knud 1748: En lappisk Grammatica efter den Dialect, som bruges af Field-Lapperne udi Porsanger-Fiorden. Kiøbenhavn.

Leem, Knud 1768: Lexicon Lapponicum bipartitum, Lapponico-Danico-Latinum \& Danico-Latino-Lapponicum cum Indice latino. Pars Prima Lapponico-Danico-Latina. Nidrosiae: Seminarium Lapponicum Fridericianum. 
Lehtinen, Tapani 1979: Itämerensuomen verbien historiallista johto-oppia: suomen avajaa, karkajaa tyyppiset verbit ja niiden vastineet lähisukukielissä. MSFOu 169.

Lehtinen, Tapani 1985: Venäjän verbisemantiikkaa itämerensuomessa: karjalan ja vepsän inkoatiiviverbit. - Sananjalka 27: 63-84.

Lehtiranta, Juhani 1992: Arjeploginsaamen äänne-ja taivutusopin pääpiirteet. MSFOu 212.

Lindahl, Erik \& Öhrling, Johannes 1780: Lexicon Lapponicum, cum interpretatione vocabularum sveco-latina et indice svecano-lapponico. Holmiae. [A modernized version available at http://www.raamesuenne.se/Lexicon_lapponicum_20160330.pdf]

LpD = Nielsen, Konrad 1979 [1932-62]: Lappisk (samisk) ordbok / Lapp Dictionary 1-5. Based on the Dialects of Polmak, Karasjok and Kautokeino. 2. opplag. Institutet for sammenlignende kulturforskning, Serie B: 17. Oslo.

LSFU $=$ Lexica Societatis Fenno-Ugricae. Helsinki: Société Finno-Ougrienne.

Luutonen, Jorma \& Mosin, Mikhail \& Shchankina, Valentina 2004: Reverse Dictionary of Mordvin. LSFU 25.

Magga, Ole Henrik 2003: Knud Leem som utforsker av samisk språk og kultur. - J. R. Hagland \& S. Supphellen (ed.), Knud Leem og det samiske. Det Kongelige Norske Videnskabers Selskap. Skrifter 2, 2003. Trondheim: Tapir Akademisk forlag. 29-43.

$\mathrm{MdWb}=H$. Paasonens Mordwinisches Wörterbuch. I-VI. Zusammengestellt von Kaino Heikkilä, Bearbeitet und herausgegeben von Martti Kahla. LSFU 23. 1990-1999.

Mosnikoff, Jouni \& Sammallahti, Pekka 1988: U'cc sää'm-lää'dd sää'nnǩeârjaž. Pieni koltansaame-suomi sanakirja. [Ohcejohka:] Jorgaleaddji.

MSFOu = Mémoires de la Société Finno-Ougrienne. Helsinki.

Nickel, Klaus Peter 1994: Samisk grammatikk. 2. utgave. [Karasjok:] Davvi Girji.

Nielsen, Konrad 1979 [1926]: Larebok i lappisk. I. Grammatikk. Oslo: Universitetsforlaget.

Posti, Lauri 1942: Grundzüge der livischen Lautgeschichte. MSFOu 85.

Puura, Ulriikka 2010: Frequentative and momentative verbal derivation in Veps language. Linguistica Uralica 46: 261-280.

Rask, Rasmus 1832: Rcesonneret lappisk Sproglcere efter den Sprogart, som bruges af Fjoeldlapperne i Porsangerfjorden i Finmarken. København.

Ravila, Paavo 1929: Über eine doppelte vertretung des urfinnischwolgaischen * $a$ der nichtersten silbe im mordwinischen. - Finnisch-Ugrische Forschungen 20: 83-120.

Ruong, Israel 1943: Lappische Verbalableitung dargestellt auf Grundlage des Pitelappischen. Uppsala.

Sammallahti, Pekka 1977: Bridging the gap between two inchoative suffixes: -škande- and Lapp -škoatte-. - Finnisch-Ugrische Forschungen 42: 192-194.

Sammallahti, Pekka 1989: Sámi-suoma sátnegirji / Saamelais-suomalainen sanakirja. Ohcejohka: Jorgaleaddji.

Sammallahti, Pekka 1998: The Saami languages. An introduction. Kárášjohka: Davvi Girji.

Sammallahti, Pekka 2007: Inarinsaamen käänteissanakirja. Inari Saami reverse dictionary. Publications of the Giellagas Institute 6. Oulu: Oulun yliopisto.

Sammallahti, Pekka \& Mosnikoff, Jouni 1991: Suomi-koltansaame sanakirja / Lää'dd-sää'm sä̈̈'nnǩe'rjj. Ohcejohka: Girjegiisá.

Schlachter, Wolfgang 1958: Wörterbuch des Waldlappendialekts von Malå und Texte zur Ethnographie. LSFU XIV.

Setälä, E. N. 1899: Yhteissuomalainen äännehistoria. Helsinki: Suomalaisen Kirjallisuuden Seura.

SKES $=$ Suomen kielen etymologinen sanakirja 1-6. Y. H. Toivonen \& Erkki Itkonen \& Aulis J. Joki \& Reino Peltola. LSFU XII. 1955-1978. 
SSA = Suomen sanojen alkuperä. Etymologinen sanakirja. 1-3. Ed. Erkki Itkonen \& UllaMaija Kulonen. Helsinki: Kotimaisten kielten tutkimuskeskus \& Suomalaisen Kirjallisuuden Seura. 1992-2000.

Štekauer, Pavol 2014: Derivational paradigms. - Rochelle Lieber \& Pavol Štekauer (eds.), The Oxford handbook of derivational morphology. New York: Oxford University Press. 354-369.

Stockfleth, N. V. 1840: Grammatik $i$ det lappiske Sprog, saaledes som det tales i Norsk-Finmarken. Förste Del. Bogstav- og Formlceren. Christiania.

Szabó, László 1967: Kolalappische Volksdichtung (Texte aus den Dialekten in Kildin und Ter). Abhandlungen der Akademie der Wissenschaften in Göttingen, 3. Folge, Philologisch-historische Klasse, 68. Göttingen: Vandenhoeck \& Ruprecht.

Szabó, László 1968: Kolalappische Volksdichtung (Texte aus den Dialekten in Kildin und Ter). Zweiter Teil nebst grammatischen Aufzeichnungen. Abhandlungen der Akademie der Wissenschaften in Göttingen, 3. Folge, Philologisch-historische Klasse, 72. Göttingen: Vandenhoeck \& Ruprecht.

Szabó, László 1987: The use of the inchoative in Kola-Sami sentences. - Nordlyd 13: 70-103.

Tunkelo, E. A. 1946: Vepsän kielen äännehistoria. Helsinki: Suomalaisen Kirjallisuuden Seura.

Turunen, Aimo 1973: Vepsän ja lyydin verbinjohtimet -ganden -gänden ja -škanden -škänden. - Commentationes fenno-ugricae in honorem Erkki Itkonen. MSFOu 150: 433-452.

Virtaranta, Pertti 1986: Haljärven lyydiläismurteen muoto-oppia. MSFOu 190.

Wilbur, Joshua (ed.) 2016: Pitesamisk ordbok samt stavningsregler. Samica 2. Freiburg: Department of Scandinavian Studies, University of Freiburg.

Ylikoski, Jussi 2009: Non-finites in North Saami. MSFOu 257.

Ylikoski, Jussi 2016: Degrammaticalization in North Saami: development of adpositions, adverbs and a free lexical noun from inflectional and derivational suffixes. - FinnischUgrische Mitteilungen 40: 113-173.

Zajceva 1978 = Зайцева, М. И.: Суффиксальное глагольное словообразование в вепсском языке. Ленинград: Наука.

Zajceva \& Mullonen 1972 = Зайцева, М. И. \& Муллонен, М. И.: Словарь вепсского языка. Ленинград: Наука. 